OPEN ACCESS

Edited by:

Camille Eichelberger Granada, University of Taquari Valley, Brazil

Reviewed by: Luciano Kayser Vargas,

Fepagro, Brazi Narsingh Chauhan, MDU Rohtak, India

${ }^{*}$ Correspondence:

Peng Si

sipeng@caas.cn

Guoliang Wu

wglhnnd@163.com

tThese authors have contributed equally to this work

Specialty section:

This article was submitted to Plant Microbe Interactions,

a section of the journal

Frontiers in Microbiology

Received: 13 September 2018 Accepted: 04 December 2018 Published: 18 December 2018

Citation:

Si $P$, Shao $W$, Yu $H$, Yang $X$, Gao $D$, Qiao X, Wang Z and Wu G (2018) Rhizosphere Microenvironments of Eight Common Deciduous Fruit Trees Were Shaped by Microbes in Northern China. Front. Microbiol. 9:3147. doi: 10.3389/fmicb.2018.03147

\section{Rhizosphere Microenvironments of Eight Common Deciduous Fruit Trees Were Shaped by Microbes in Northern China}

\author{
Peng Si ${ }^{1 \star t}$, Wei Shao ${ }^{1,2 t}$, Huili Yu ${ }^{1}$, Xiaojing Yang ${ }^{1}$, Dengtao Gao ${ }^{1}$, Xiansheng Qiao ${ }^{1}$, \\ Zhiqiang Wang ${ }^{1}$ and Guoliang $W^{2,3 *}$

\begin{abstract}
${ }^{1}$ Laboratory of Cultivation Physiology, Zhengzhou Fruit Research Institute, Chinese Academy of Agricultural Sciences, Zhengzhou, China, ${ }^{2}$ College of Forestry, Henan Agricultural University, Zhengzhou, China, ${ }^{3}$ College of Horticulture, Henan Agricultural University, Zhengzhou, China
\end{abstract}

The rhizosphere microenvironment is the site of nutrient circulation and microbial community formation, and thus is an ongoing topic of research. Although research on this topic is extensive, studies into the rhizosphere microenvironment of fruit trees remain rare. To elucidate the mechanisms driving the fruit tree rhizosphere microenvironment, we assessed soil physicochemical properties, enzyme activities, the community-level physiological profile (CLPP) and microbial diversity in rhizospheric soils of eight common deciduous fruit trees in northern China. We found that the available minerals, $\mathrm{pH}$, enzyme activities, microbial utilization of six types of carbon (C) substrates, and microbial diversity in the rhizosphere varied among tree species. Redundancy analysis (RDA) showed that rhizosphere microenvironmental parameters (ammonia nitrogen content, soil $\mathrm{pH}$ and invertase activity) were closely related to the soil microbial community. Further analysis revealed that the soil microbial utilization of six $\mathrm{C}$ sources, nitrate nitrogen content, and invertase activity were negatively correlated with Ambiguous species and Alternaria; however, these groups were positively correlated with $\mathrm{pH}$. The ammonia nitrogen content was positively correlated with $\mathrm{C}$ source utilization and negatively correlated with Ambiguous, Lysobacter, Nitrospira, Alternaria, Fusarium, and Colletotrichum. Interestingly, invertase was closely linked to the microbial community, especially fungal diversity, and was positively correlated with plant-beneficial microbes such as Mortierella, Geomyces, Lysobacter, and Chaetomium, but negatively correlated with pathogenic microbes such as Alternaria, Fusarium, and Colletotrichum. Hence, rhizosphere soil physicochemical properties, enzyme activities and microbial community were significantly affected by tree species. Additionally, a variety of environmental factors were closely related to the microbial community in the rhizospheric soils of eight species of deciduous fruit trees.

Keywords: deciduous fruit trees, rhizosphere microenvironment, soil physicochemical properties, soil enzyme activity, soil microbial community, redundancy analysis, Pearson correlation 


\section{INTRODUCTION}

Deciduous fruit trees have been planted north of the Yangtze River in China, including apples, pears, walnuts, peaches, grapes, cherries,apricots, etc. (Tian and Zhang, 2017). The rapid growth of deciduous fruit production in recent years has become an important force driving the growth of fruit crops worldwide (Feng et al., 2014; Srivastava et al., 2015). The rhizosphere, which links root traits to functions, is the site of nutrient acquisition, nutrient cycling and microbial community formation (Mommer et al., 2016; Chen et al., 2017), and affects not only fruit tree growth, but also the yield and quality of fruit (Babu et al., 2015; Mazzola et al., 2015; Soni et al., 2016). Research into the differences and commonalities of the rhizosphere environment among different deciduous fruit trees in northern China may facilitate better understanding of the rhizosphere of different tree species, improve scientific knowledge to inform more effective fertilization methods in the future, and finally, generate new ideas for the development of specialized fruit tree fertilizers. Recently, the Chinese government proposed a policy to reduce the use of pesticides and fertilizers and thus curb the trend of increasing agricultural nonpoint-source pollution. The traditional fertilization method in China has disadvantages, including low efficiency of fertilizer utilization and water waste (Liu et al., 2010; Miao et al., 2011). Therefore, elucidating the mechanisms underlying fruit tree rhizosphere microenvironments is necessary.

The rhizosphere is the narrow zone of soil that surrounds roots and is influenced by plant root exudates (Philippot et al., 2013; Qiu et al., 2014). The chemistry of the rhizosphere can be affected by plant roots in various ways, including through release and uptake of organic compounds, the gas exchange associated with respiration of roots and rhizosphere microorganisms, and root absorption and release of water and nutrients (Neumann and Römheld, 2014). Moreover, the physical properties of rhizosphere soil are modified by root growth through the soil and the presence of polymeric substances (Marschner, 2012; Neumann and Römheld, 2014). The rhizosphere ecosystem of fruit trees is based on a fruit tree-soil-microbe relationship and their interactions with environmental conditions; a harmonious rhizosphere ecosystem developed through fertilization is beneficial for nutrient absorption and normal growth and development of fruit trees (Zhang et al., 2009). Hence, the application of fertilizer and the rhizosphere environment have a close relationship.

The rhizosphere effect states that plants release up to $40 \%$ of their photosynthetic products into the rhizosphere (Singh et al., 2017), resulting in a phenomenon in which the rhizosphere microbial population density is much higher than that in the surrounding bulk soil (Bais et al., 2006; Berendsen et al., 2012). In the rhizosphere, $10^{11}$ microbial cells per gram of root and more than 30,000 prokaryotic species are present, making it one of the most dynamic interfaces on Earth (Egamberdieva et al., 2010; Berendsen et al., 2012; Philippot et al., 2013). According to their effects on plant growth, rhizosphere microbes are divided into beneficial microbes, deleterious rhizosphere microbes, and neutral microbes exerting no direct effects on pathogens or plants (Hu et al., 2004). Plant-beneficial microbes have been widely studied for their positive effects on plant growth and health (Lugtenberg, 2015). They can facilitate nitrogen (N), phosphorus $(\mathrm{P})$, and mineral uptake by the plant, and can also secrete plant hormones into the rhizosphere to promote plant growth (Oberhänsli et al., 1991; Bottini et al., 2004). These microbes can produce secondary metabolites such as HCN, 2,4diacetylphloroglucinol and pyoluteorin to antagonize pathogenic fungi, thereby indirectly promoting plant growth (Defago et al., 1990). In addition, they can directly or indirectly participate in the auxin pathway and modulate the plant root architecture, in turn affecting the absorption of nutrients during beneficial plantmicroorganism interactions (Sukumar et al., 2013). Thus, plantbeneficial microbes might also increase soil nutrient uptake, reducing the need for fertilizers and preventing the accumulation of nitrates and phosphates in agricultural soils (Yang et al., 2009; Hongoh and Ohkuma, 2011). Deleterious microbes cause major yield reductions in economic crops (Oerke et al., 1994). In particular, plant pathogenic fungi are a more significant problem than plant pathogenic bacteria in temperate climates (Mendes et al., 2013). In the rhizosphere, a fierce battle is fought between plant-beneficial microbes and deleterious microbes (Berendsen et al., 2012). Hence, the composition of the microbial community in the rhizosphere plays a crucial role in the function of plants through influences on their physiology and development (Mendes et al., 2013).

Here, we compared the rhizosphere soil in terms of physicochemical properties, enzyme activity, community-level physiological profile (CLPP) and microbial structure diversity among eight deciduous fruit trees that are common in northern China, and analyzed the relationship between rhizosphere microbes and microenvironmental factors.

\section{MATERIALS AND METHODS}

\section{Site Description}

The experiment was performed at Xinxiang Integrated Test Base, Zhengzhou Fruit Research Institute, Chinese Academy of Agricultural Sciences $\left(35^{\circ} 7^{\prime} 40^{\prime \prime} \mathrm{N}, 113^{\circ} 45^{\prime} 57^{\prime \prime} \mathrm{E}\right)$, located in the Henan Province of China. The average elevation of the study area was $80 \mathrm{~m}$ above sea level. The climate was a typical temperate continental monsoon climate with a mean annual temperature of $14^{\circ} \mathrm{C}$. Mean annual precipitation was $\sim 573.4 \mathrm{~mm}$. The topsoil contained $125.89 \mathrm{mg} / \mathrm{kg}$ available $\mathrm{P}, 202.6 \mathrm{mg} / \mathrm{kg}$ available potassium $(\mathrm{K}), 1.39 \mathrm{mg} / \mathrm{kg}$ ammonia nitrogen, and $5.62 \mathrm{mg} / \mathrm{kg}$ nitrate nitrogen, with a $\mathrm{pH}-\mathrm{H}_{2} \mathrm{O}$ of 8.05 .

\section{Experimental Design}

In March 2012, deciduous fruit trees of eight species were planted in northern China: apples (strain: Huashuo; rootstock: Malus robusta Rehd.), pears (strain: Wanqiuhuangli; rootstock: Pyrus betulaefolia Bge.), apricots (strain: Katy apricot; rootstock: selfrooted), cherries (strain: Longguan; rootstock: ZY-1), peaches, (strain: Zhongyou 4; rootstock: Prunus davidiana), grapes (strain: Kyoho grape; rootstock: self-rooted), walnuts (strain: Zhonghe 1; rootstock: self-rooted) and pomegranates (strain: Tunisia; rootstock: self-rooted). A plot that was not planted with fruit 
trees was used as a control (CK). Nine trees (plant spacing: $3 \mathrm{~m} \times$ $3 \mathrm{~m}$ ) were planted in each plot (plot area: $36 \mathrm{~m}^{2}$ ). A randomized complete block design was utilized with three replications. To avoid interference, each blank plot was situated between two adjacent plots. A total of $375 \mathrm{~kg} /$ ha of compound fertilizer (N, $\mathrm{P}_{2} \mathrm{O}_{5}$, and $\mathrm{K}_{2} \mathrm{O}$, each at $15 \%$ ) and $9,000 \mathrm{~kg} / \mathrm{ha}$ of organic fertilizer was applied every September to all plots. No other chemicals were used in any of the plots.

\section{Soil Sampling}

Rhizosphere soil samples were collected in May 2017. The deciduous layer was first removed. Then, the rhizosphere soil $10-20 \mathrm{~cm}$ above the ground was collected, placed in a sterile bag, and stored on ice. The soil samples were passed through a $2-\mathrm{mm}$ aperture sterile screen. Within each plot, three trees were randomly selected for rhizosphere soil collection, and three rhizospheric soils were mixed into one soil sample. Thus, each treatment includes three replicates. All samples were subsequently stored at $-80^{\circ} \mathrm{C}$.

\section{Measurement of Soil Physicochemical Properties}

The $\mathrm{pH}$ was measured using a $\mathrm{pH}$ meter (PHS-3C; Leici, Shanghai, China) at a $1: 5(\mathrm{w} / \mathrm{v})$ ratio of soil to distilled water (Lu, 2000). The soil organic matter (SOM) content was determined using a colorimetric method involving oxidation with potassium dichromate (Nelson and Sommers, 1996). Nitrate $\left(\mathrm{NO}_{3}^{-}-\mathrm{N}\right)$ and ammonium $\left(\mathrm{NH}_{4}^{+}-\mathrm{N}\right)$ were extracted using $1.0 \mathrm{M} \mathrm{KCl}$ at a 1:10 soil-to-solution ratio. After shaking for $1 \mathrm{~h}$, the extracts were filtered and then measured using an Automated Discrete Analyzer (CleverChem 380'DeChem-Tech Inc., Hamburg, Germany) (Lu, 2000). The available $\mathrm{K}$ was extracted in $1 \mathrm{M}$ ammonium acetate using flame photometry [FP6431; INASA Inc., Shizuoka, Japan (Lu, 2000)]. The available $\mathrm{P}$ was extracted from the soil sample with $0.5 \mathrm{M} \mathrm{NaHCO}_{3}(\mathrm{pH}$ 8.5) and measured spectrophotometrically (Tu-1901; Persee Inc., Beijing, China) as blue molybdate-phosphate complexes formed through partial reduction with ascorbic acid (Lu, 2000).

\section{Soil Enzyme Activities}

According to the method described by Yao and Huang (2006), the invertase activity was measured. Briefly, $2 \mathrm{~g}$ of fresh soil was incubated with $15 \mathrm{~mL}$ of $8 \%$ sucrose, $5 \mathrm{~mL}$ of phosphate buffer ( $\mathrm{pH}$ 5.5), and five drops of methylbenzene at $37^{\circ} \mathrm{C}$ for $24 \mathrm{~h}$, and the reducing sugars released were then analyzed at $508 \mathrm{~nm}$ using a spectrophotometer (Yu et al., 2016) (Tu-1901; Persee Inc.). Urease activity was determined as described by Yao and Huang (2006). Five grams of fresh soil was incubated with $1 \mathrm{~mL}$ of methylbenzene, $10 \%$ urea and $20 \mathrm{~mL}$ of citrate buffer ( $\mathrm{pH}$ 6.7) at $37^{\circ} \mathrm{C}$ for $24 \mathrm{~h}$. Then, the content of p-nitrophenol was measured at $578 \mathrm{~nm}$ using a spectrophotometer (Yu et al., 2016) (Tu-1901; Persee Inc.). Catalase activity was measured according to Li et al. (2008) by incubating $2 \mathrm{~g}$ of fresh soil sample with $40 \mathrm{~mL}$ of distilled water and $5 \mathrm{~mL}$ of $0.3 \% \mathrm{H}_{2} \mathrm{O}_{2}$ at 120 rpm for $20 \mathrm{~min}$, and then $25 \mathrm{~mL}$ of the filtrate was titrated with $\mathrm{KMnO}_{4}$ after adding $5 \mathrm{~mL}$ of $1.5 \mathrm{~mol} / \mathrm{L} \mathrm{H}_{2} \mathrm{SO}_{4}$ to terminate the reaction ( $\mathrm{Yu}$ et al., 2016). The alkaline phosphatase activity was measured according to the method described by Guan (1986), by incubating $2 \mathrm{~g}$ of fresh soil with $20 \mathrm{~mL}$ of borate saline buffer $(\mathrm{pH} 9.6)$ and five drops of methylbenzene at $37^{\circ} \mathrm{C}$ for $24 \mathrm{~h}$. The content of p-nitrophenol in the filtrate was determined using a spectrophotometer at $660 \mathrm{~nm}$ (Yu et al., 2016) (Tu1901; Persee Inc.). The $\beta$-glucosidase activity was measured according to the method described previously by Eivazi and Tabatabai (1988). Briefly, $1 \mathrm{~g}$ of fresh soil was incubated with $4 \mathrm{~mL}$ of phosphate buffer $(\mathrm{pH}=6.0)$ and $1 \mathrm{~mL}$ of substrate $(\mathrm{p}$ nitrophenyl- $\beta$-d-glucopyranoside) at $37^{\circ} \mathrm{C}$ for $1 \mathrm{~h}$. Then, $1 \mathrm{~mL}$ of $0.5-\mathrm{mol} / \mathrm{L} \mathrm{CaCl} \mathrm{Cl}_{2}$ and $4 \mathrm{~mL}$ of Tris buffer ( $\mathrm{pH}$ 12) were added to stop the reaction, and the filtrate was measured using a spectrophotometer at $400 \mathrm{~nm}$ (Yu et al., 2016) (Tu-1901; Persee Inc.). Cellulase activity was estimated as described by Schinner and Von Mersi (1990). Briefly, $1 \mathrm{~g}$ of fresh soil was incubated with $10 \mathrm{~mL}$ of $2 \mathrm{M}$ acetate buffer (pH 5.5) containing carboxymethyl cellulose sodium salt $(0.7 \%)$ for $24 \mathrm{~h}$ at $50^{\circ} \mathrm{C}$. Then, the filtrates of the soil-substrate slurries were subjected to a color reaction, and the Prussian blue produced was analyzed colorimetrically in a microplate reader at $690 \mathrm{~nm}$ (Bio-Rad, Hercules, CA, USA).

\section{Analysis of the Community-Level Physiological Profile (CLPP)}

A CLPP was constructed using the Biolog EcoPlate (Biolog Inc., Hayward, CA, USA). Each Biolog EcoPlate contained 31 carbon (C) sources in triplicate as well as three negative controls in a 96-well-plate format (Montes-Borrego et al., 2013). Briefly, $1 \mathrm{~g}$ of soil and $99 \mathrm{ml}$ of $0.85 \%$ sterilized $\mathrm{NaCl}$ solution were added to an autoclaved triangular flask, and the flask was shaken at $120 \mathrm{rpm}$ for $30 \mathrm{~min}$ and then stored at $4^{\circ} \mathrm{C}$ for $30 \mathrm{~min}$. A total of $150 \mu \mathrm{L}$ of the resulting solution was placed in each well, and cultivated at $25^{\circ} \mathrm{C}$ for $192 \mathrm{~h}$. Then, the plates were read every $24 \mathrm{~h}$ by the Biolog MicroStation ${ }^{\mathrm{TM}}$ reader at both 590 and $750 \mathrm{~nm}$ (Guanghua et al., 2008) (Biolog Inc.). Biolog EcoPlate substrates were divided into six groups based on $\mathrm{C}$ sources (PM, polymers; $\mathrm{CH}$, carbohydrate; $\mathrm{PC}$, phenolic compounds; CA, carboxylic acids; AA, amino acids; AN, amines) (Choi and Dobbs, 1999; Rutgers et al., 2016; Kolton et al., 2017). The 96-h data, which were collected in the exponential phase, were used for constructing the CLPPs of deciduous fruit trees. Principal component analysis (PCA) was used to assess tree species-related differences in CLPPs after normalization of the absorbance associated with each substrate (Kolton et al., 2017), and the utilization of the six C source groups was calculated to assess tree speciesspecific catabolic activity (Jiang et al., 2013; Wu et al., 2013).

\section{DNA Extraction and Polymerase Chain Reaction (PCR)}

The total genomic DNA was extracted from each soil sample using TIANamp Soil DNA Kit 107 (Tiangen Biotech Inc., Beijing, China) following the manufacturer's instructions. The quality and integrity of the DNA were assessed based on its A260/280 ratio and agarose gel electrophoresis. The DNA extracted from 
three independent soil samples served as a template to amplify the $16 \mathrm{~S}$ rRNA gene and the internal transcribed spacer (ITS) region. The bacterial $16 \mathrm{~S}$ rRNA gene was amplified with the universal primer pair B341F (5'-CCTACGGGNGGCWGCAG$\left.3^{\prime}\right)$ and B785R (5'-GACTACHVGGGTATCTAATCC-3') (Klindworth et al., 2013). The fungal-specific primers, ITS3F (5'-GATGAAGAACGYAGYRAA-3') and ITS4R (5'TCCTCCGCYYATTGATATGC- $3^{\prime}$ ), were employed to amplify the fungal ITS region (Toju et al., 2012). PCR amplification was performed using the KAPA HiFiHot Start ReadyMix PCR Kit in a GeneAmp PCR System 9700 instrument (Life Technologies, Carlsbad, CA, USA). The PCR reactions were conducted with $25-\mu \mathrm{L}$ total volume reaction cocktails consisting of $12.5 \mu \mathrm{L}$ of KAPA HiFi HotStart ReadyMix $(2 \times), 0.25 \mu \mathrm{mol} \mathrm{L}{ }^{-1}$ of each primer and $10 \mathrm{ng}$ of the DNA template. Amplification was performed with the following thermal profile: $3 \mathrm{~min}$ of initial denaturation at $95^{\circ} \mathrm{C}$ followed by 25 cycles of denaturation at $95^{\circ} \mathrm{C}$ for $30 \mathrm{~s}$, annealing at $55^{\circ} \mathrm{C}$ for $30 \mathrm{~s}$, extension at $72^{\circ} \mathrm{C}$ for $30 \mathrm{~s}$, and then a final extension at $72^{\circ} \mathrm{C}$ for $5 \mathrm{~min}$. After purification, the PCR products were quantified using 2100 Bioanalyzer System (Agilent Inc., Santa Clara, CA, USA) (Mueller et al., 2000) and pooled at equal concentrations. Then, amplicon sequencing was performed using a MiSeq platform (Illumina, San Diego, CA, USA) at Genewiz, Inc. (Suzhou, China).

\section{Data Analysis}

The 16S rRNA and ITS data were analyzed using the QIIME (Quantitative Insights Into Microbial Ecology; ver. 1.9.1) data analysis package (Li et al., 2017; Qiao et al., 2018; Zhang et al., 2018). Operational taxonomic units (OTUs) at $97 \%$ similarity were used to perform rarefaction analysis, and to calculate the richness and diversity indexes. Details of the sequencing data are shown in Tables S1, S2. Sample normalization was conducted through rarefaction. The Chao and Shannon indices were calculated as measures of microbial richness and diversity. Microbial parameter data were analyzed using one-way analysis of variance with tree species as the factor. The values were considered significantly different at a $95 \%$ confidence level. Values shown in figures and tables correspond to the average of triplicate data \pm standard error (SE). At the phylum level, the relative abundances of 7 major bacterial phyla ( $>1.0 \%$ of total composition in all samples) and 4 major fungal phyla ( $>0.01 \%$ of total composition in all samples) were shown using one-way analysis of variance with tree species as the factor. Principal coordinates analysis (PCoA) was performed using the OTU data to identify differences in microbial communities between the control and treatment soils. The heatmap figures, PCoA and Venn diagrams were produced using R Package. The PCA was performed using Canoco 4.5 Microcomputer Power, Ithaca, NY, USA).

\section{Data Availability}

The sequence reads generated in this project are available online (http://www.ncbi.nlm.nih.gov/sra) under accession number SRP161632.

\section{RESULTS}

\section{Rhizosphere Soil Physicochemical Properties and Enzyme Activities}

The available nutrient contents and $\mathrm{pH}$ of the rhizosphere soil differed significantly among the eight deciduous fruit tree species sampled at the initial fruiting stage in northern China (Table 1 and Table S3). The rhizosphere soil available mineral contents (except available $\mathrm{P}$, calcium and magnesium) were obviously greater, while the $\mathrm{pH}$ was significantly lower, for the deciduous fruit trees compared to the control samples. A detailed comparison among trees showed that the walnut and pomegranate soil $\mathrm{pH}$ levels were lower than those of other deciduous fruit trees. Among the fruit trees, the apple soil had the highest ammonia nitrogen content and the lowest nitrate nitrogen content, while the pear soil showed the opposite pattern. The available K content of peach soil was much higher than of the other samples, while the lowest available $\mathrm{K}$ content was found in the grape and cherry soils. The available $\mathrm{P}$ content of the walnut soil was significantly higher than that of the other fruit trees, while the grape, pomegranate, apricot, cherry, and peach soils had markedly less available $\mathrm{P}$. The organic matter (OM) content of the walnut soil was greatest, while that of apple was lowest.

TABLE 1 | Rhizosphere soil physicochemical properties of different deciduous fruit trees in northern China.

\begin{tabular}{|c|c|c|c|c|c|c|}
\hline & $\mathrm{pH}$ & $\mathrm{NH}_{4}-\mathrm{N}(\mathrm{mg} / \mathrm{kg})$ & $\mathrm{NO}_{3}-\mathrm{N}(\mathrm{mg} / \mathrm{kg})$ & Available K (mg/kg) & Available P (mg/kg) & Organic matter $(\mathrm{g} / \mathrm{kg})$ \\
\hline CK & $8.05 \pm 0.03 a$ & $1.39 \pm 0.42 f$ & $5.62 \pm 0.2 d$ & $202.6 \pm 1.16 f$ & $125.89 \pm 0.85 c$ & $16.31 \pm 0.36 \mathrm{e}$ \\
\hline Grape & $7.25 \pm 0.03 e$ & $2.23 \pm 0.13 \mathrm{ef}$ & $6.63 \pm 0.67 \mathrm{~cd}$ & $231.2 \pm 5.65 \mathrm{ef}$ & $21.33 \pm 0.65 e$ & $19.55 \pm 0.07 d$ \\
\hline Walnut & $6.95 \pm 0.03 \mathrm{~g}$ & $5.71 \pm 0.26 \mathrm{ab}$ & $6.73 \pm 0.62 \mathrm{~cd}$ & $356.67 \pm 3.39 c$ & $296.1 \pm 10.11 a$ & $32.91 \pm 0.38 a$ \\
\hline Pomegranate & $7 \pm 0.06 g$ & $4.9 \pm 0.56 b c$ & $10.37 \pm 0.14 b$ & $454.37 \pm 8.04 b$ & $34.85 \pm 1.15 \mathrm{de}$ & $22.78 \pm 0.25 c$ \\
\hline Apricot & $7.8 \pm 0 b$ & $3.23 \pm 0.12 \mathrm{de}$ & $7.83 \pm 0.04 c$ & $282.93 \pm 2.36 d$ & $29.12 \pm 1.52 \mathrm{de}$ & $23.13 \pm 0.12 c$ \\
\hline Cherry & $7.3 \pm$ Ode & $3.73 \pm 0.21 d$ & $6.33 \pm 0.04 \mathrm{~cd}$ & $240.4 \pm 0.86 e$ & $35.62 \pm 1.88 \mathrm{de}$ & $24.61 \pm 0.03 b$ \\
\hline Peach & $7.35 \pm 0.03 d$ & $4.27 \pm 0.59 \mathrm{~cd}$ & $10.09 \pm 0.6 b$ & $555.62 \pm 31.23 a$ & $40.58 \pm 1.48 d$ & $19.9 \pm 0.18 d$ \\
\hline Apple & $7.15 \pm 0.03 f$ & $6.16 \pm 0.4 a$ & $6.01 \pm 1.02 d$ & $483.83 \pm 4.97 b$ & $119.61 \pm 8.45 c$ & $16.73 \pm 0.12 e$ \\
\hline Pear & $7.7 \pm 0 c$ & $1.91 \pm 0.27 f$ & $12.68 \pm 0.26 a$ & $323.53 \pm 2.11 c$ & $214.45 \pm 1.17 b$ & $23.06 \pm 0.3 c$ \\
\hline
\end{tabular}

Values are means \pm SE. Suffixes in the same row indicate statistical significance at $p<0.05$ using one-way analysis of variance with tree species as the factor. 
The available zinc and copper contents of walnut rhizosphere soil were highest, while those of apricot soil were lowest. The available content of trace elements in the cherry rhizosphere soil was generally low. The iron and calcium contents of apple and pear rhizospheric soils were higher than the others. Among these fruit trees, the available boron content of peach was the highest, and grape had the highest available magnesium. Hence, significant differences were observed in rhizosphere soil available nutrient contents and $\mathrm{pH}$ among fruit trees at the initial fruiting stage.

Furthermore, the activity of various soil enzymes was markedly affected by the fruit tree species (Table 2). Soil urease, a key enzyme involved in soil $\mathrm{N}$ cycling, can catalyze the hydrolysis of urea into ammonia. Among the fruit trees, the urease activity in the walnut soil was significantly higher than that in the others; the peach and apple soils had the lowest urease activities. There were no significant differences among the soils of the grapes, apricots, and cherries. Soil alkaline phosphatase hydrolyzes organic $\mathrm{P}$ in the soil into available $\mathrm{P}$, which can be used by the crop. In the fruit tree rhizosphere, the alkaline phosphatase activity of apricot was significantly higher than that of the other species, while grape, peach, and apple exhibited relatively low alkaline phosphatase activity. Catalase promotes the decomposition of hydrogen peroxide into water and oxygen and can reduce the toxic effects of hydrogen peroxide on plants. Sucrase is related to multiple soil factors, including SOM, N, and P content, microbial abundance, and soil respiration rate. Catalase and sucrase activities were highest in the pomegranate soil, while the soils from the apple subfamily (apple and pear) had the lowest catalase and sucrose activities. Cellulase helps to degrade cellulose and is an important enzyme in the $\mathrm{C}$ cycle. Among all trees tested, the cellulase activity was highest in the soil from the grape tree. Interestingly, the cellulase activities in soils of all Rosaceae crops were significantly lower than those in other soils. $\beta$-glucosidase is an essential enzyme in the $\mathrm{C}$ cycle, which degrades cellobiose, cellotriose and other low-molecular-weight dextrins into glucose. The $\beta$ glucosidase activity of the apricot soil was significantly higher than those of other species, while it was significantly lower in the soils from the grape and apple subfamily (apple and pear).

\section{Rhizosphere Soil Microbial Community-Level Physiological Profiles}

The PCA of the soil microbial CLPP showed that the various deciduous fruit trees affected the functional structure of the soil microbial community (Figure 1). Two PCAs accounted for $43.1 \%$ of the total variation and each soil sample formed its own cluster. The control clusters exhibited positive trends for PCA1 and PCA2, while the apple and pomegranate clusters were both negatively correlated with PCA1 and PCA2. Moreover, PCA analysis showed three relatively distinct groups, with the control cluster on the right side, the cherry-walnut cluster on the left side, and the other fruit trees clustered below.

The use of six substrate types (polymers, carbohydrates, phenolic compounds, carboxylic acids, amino acids, and amines) by deciduous fruit trees is shown in Figure 2. The use of these six substrates differed markedly among the deciduous fruit trees. Compared to the control, all six substrates were used more by the rhizosphere microbial communities. Moreover, apple had a positive effect on the utilization of substrates. Compared to other fruit trees, the utilization of the phenolic compounds, carboxylic acids, amino acids, and amines was reduced in pears and peaches. Meanwhile, there was no significant difference in the utilization of substrates between walnuts and apricots.

\section{Rhizosphere Soil Microbial Community Composition}

The effects of the various deciduous fruit trees on the richness and diversity of bacteria and fungi are shown in Table 3. In general, the fungal communities showed significantly lower diversity than the bacterial communities, as measured by the Chaol index, the Shannon index and the ACE index. The rhizosphere soil bacterial and fungal diversity indices were most extreme in the apple, apricot, and walnut rhizosphere. The Chaol, Shannon, and $\mathrm{ACE}$ indices of bacterial diversity in the apple rhizosphere was significantly higher than others, while they were significantly lower in apricot and walnut rhizosphere. The indices of fungal

TABLE 2 | Soil enzyme activities of different deciduous fruit trees in northern China.

\begin{tabular}{|c|c|c|c|c|c|c|}
\hline & $\begin{array}{c}\text { Urease } \\
\mathrm{NH} 3-\mathrm{N} \\
\mathrm{mg} /(\mathrm{g} \cdot 24 \mathrm{~h})\end{array}$ & $\begin{array}{c}\text { Alkaline } \\
\text { phosphatase } \\
\text { Phenol } \mathrm{mg} /(\mathrm{g} \cdot 24 \mathrm{~h})\end{array}$ & $\begin{array}{c}\text { Catalase } \\
\mathrm{H}_{2} \mathrm{O}_{2} \\
\mathrm{mg} /(\mathrm{g} \cdot 20 \mathrm{~min})\end{array}$ & $\begin{array}{l}\text { Invertase } \\
\text { glucose } \\
\mathrm{mg} /(\mathrm{g} \cdot 24 \mathrm{~h})\end{array}$ & $\begin{array}{c}\text { Cellulase } \\
\text { glucose } \mathrm{mg} /(\mathbf{g} \cdot \mathbf{h})\end{array}$ & $\begin{array}{l}\beta \text {-glucosidase } \\
\text { P-nitrophen } \\
\text { mmg/(kg·h) }\end{array}$ \\
\hline Grape & $0.53 \pm 0.04 \mathrm{~cd}$ & $0.78 \pm 0.03 e$ & $1.76 \pm 0.01 b$ & $7.05 \pm 0.14 d$ & $2.54 \pm 0.08 a$ & $32.91 \pm 1.3 d$ \\
\hline Walnut & $0.61 \pm 0.03 a$ & $1.53 \pm 0.04 a b$ & $1.78 \pm 0 a b$ & $8.84 \pm 0.17 c$ & $2.36 \pm 0.07 b$ & $133.68 \pm 10.45 c$ \\
\hline Pomegranate & $0.59 \pm 0.01 \mathrm{ab}$ & $1.43 \pm 0.05 b$ & $1.81 \pm 0.02 \mathrm{a}$ & $13.62 \pm 0.28 a$ & $2.24 \pm 0.02 b$ & $123.07 \pm 12.34 \mathrm{c}$ \\
\hline Cherry & $0.48 \pm 0.05 \mathrm{de}$ & $1.21 \pm 0.06 c$ & $1.77 \pm 0.01 b$ & $8.94 \pm 0.24 c$ & $1.4 \pm 0.03 f g$ & $127.63 \pm 7.23 c$ \\
\hline Peach & $0.46 \pm 0.03 e$ & $0.76 \pm 0 e$ & $1.69 \pm 0.01 c$ & $7.05 \pm 0.06 d$ & $1.68 \pm 0.02 d$ & $181.19 \pm 11.48 \mathrm{~b}$ \\
\hline Apple & $0.46 \pm 0.04 \mathrm{e}$ & $1.05 \pm 0.03 d$ & $1.58 \pm 0 e$ & $6.7 \pm 0.2 \mathrm{de}$ & $1.31 \pm 0.02 \mathrm{~g}$ & $41.78 \pm 2.63 d$ \\
\hline Pear & $0.56 \pm 0.02 a b c$ & $1.53 \pm 0.05 a b$ & $1.62 \pm 0.01 d$ & $6.21 \pm 0.06 \mathrm{e}$ & $1.62 \pm 0.03 \mathrm{de}$ & $42.78 \pm 2.13 d$ \\
\hline
\end{tabular}

Values are means \pm SE. Suffixes in the same row indicate statistical significance at $p<0.05$ using one-way analysis of variance with tree species as the factor. 
diversity were significantly lower in the apple soil, while they were elevated in the walnut soil. In the apricot soil, bacterial and fungal diversity indices were quite low.

To visualize the differences in rhizosphere soil microbial community structure among the fruit tree species, taxonomic abundance profiling was performed to compute a Bray-Curtis

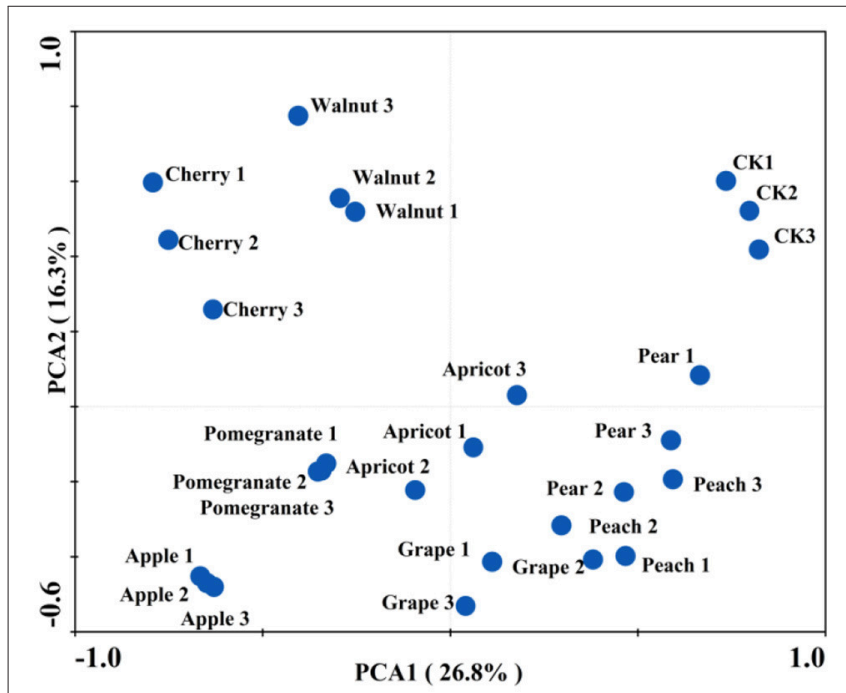

FIGURE 1 | Effect of different deciduous fruit trees on the root-associated microbial community carbon source utilization in northern China. Principal component analysis (PCA) of carbon substrate utilization patterns obtained with Biolog Eco-plates, showing different deciduous fruit trees. similarity matrix divided into two dimensions using nonmetric multidimensional scaling (NMDS) (Figure 3). NMDS analysis of the bacterial community revealed that each fruit tree species formed its own cluster. In contrast, the fungal samples were grouped into two clear clusters, with the apple group below and the other samples above. Furthermore, the fungal communities of the pomegranate, pear, and apricot soils were more similar to each other compared to the other tree species. Therefore, differences in rhizosphere soil microbial communities between the control and deciduous fruit trees lay mainly in the composition of the bacterial community, while the fungal community showed no significant differences. In addition, the apple tree played an important role in developing the fungal community and shaping rhizosphere microbial communities.

The shared OTUs among the eight species of deciduous fruit trees and the control sample were illustrated using a Venn diagram (Figure 4). In the bacterial communities, a total of 1,146 OTUs were shared by the nine samples, accounting for $73.51 \%$ of the 1,559 total OTUs obtained (Figure 4A). Some OTUs were only found in a particular bacterial community, accounting for two, three, five, eight, and six bacterial taxa in the walnut, apple, pear, pomegranate, and grape soils, respectively. Thus, $0.13,0.19$, $0.32,0.38$, and $0.51 \%$ of the detected OTUs were unique to the walnut, apple, pear, pomegranate, and grape soils, respectively. In addition, one, four, and three OTUs $(0.06,0.26$, and $0.19 \%)$ were detected only in the cherry, peach, and apricot soils, respectively. In summary, each deciduous fruit tree had its own unique bacterial taxa.

In the fungal communities, a total of 136 OTUs were shared by the nine communities, accounting for $11.8 \%$ of the

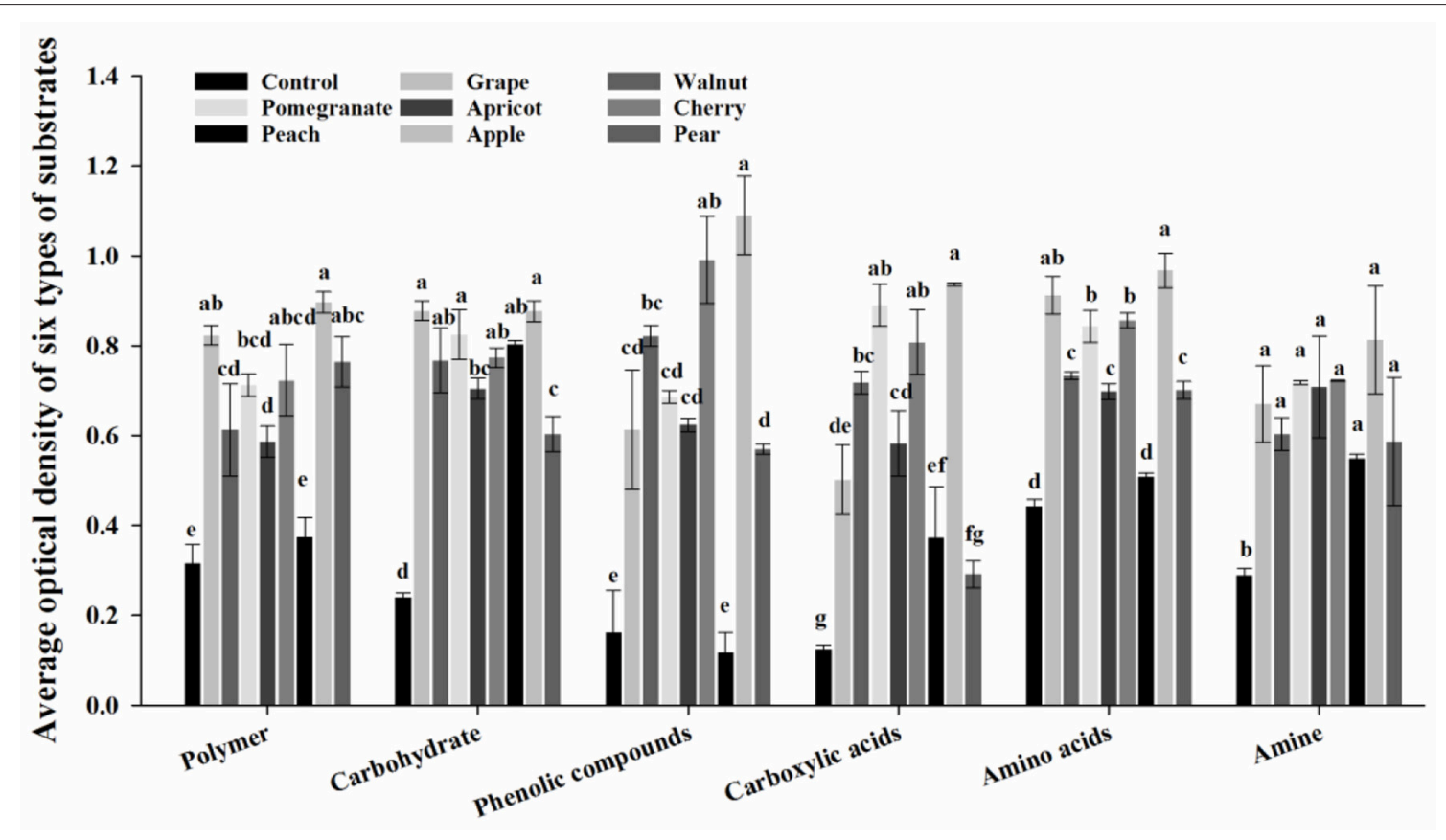

FIGURE 2 | Effect of different deciduous fruit trees on the rhizosphere microbial community utilization of six types of carbon substrates at $96 \mathrm{~h}$. Values are means \pm SE, and letters denote significant differences among trees using one-way analysis of variance with tree species as the factor. 
TABLE 3 | Bacterial and fungal a-diversity indexes of different deciduous fruit trees.

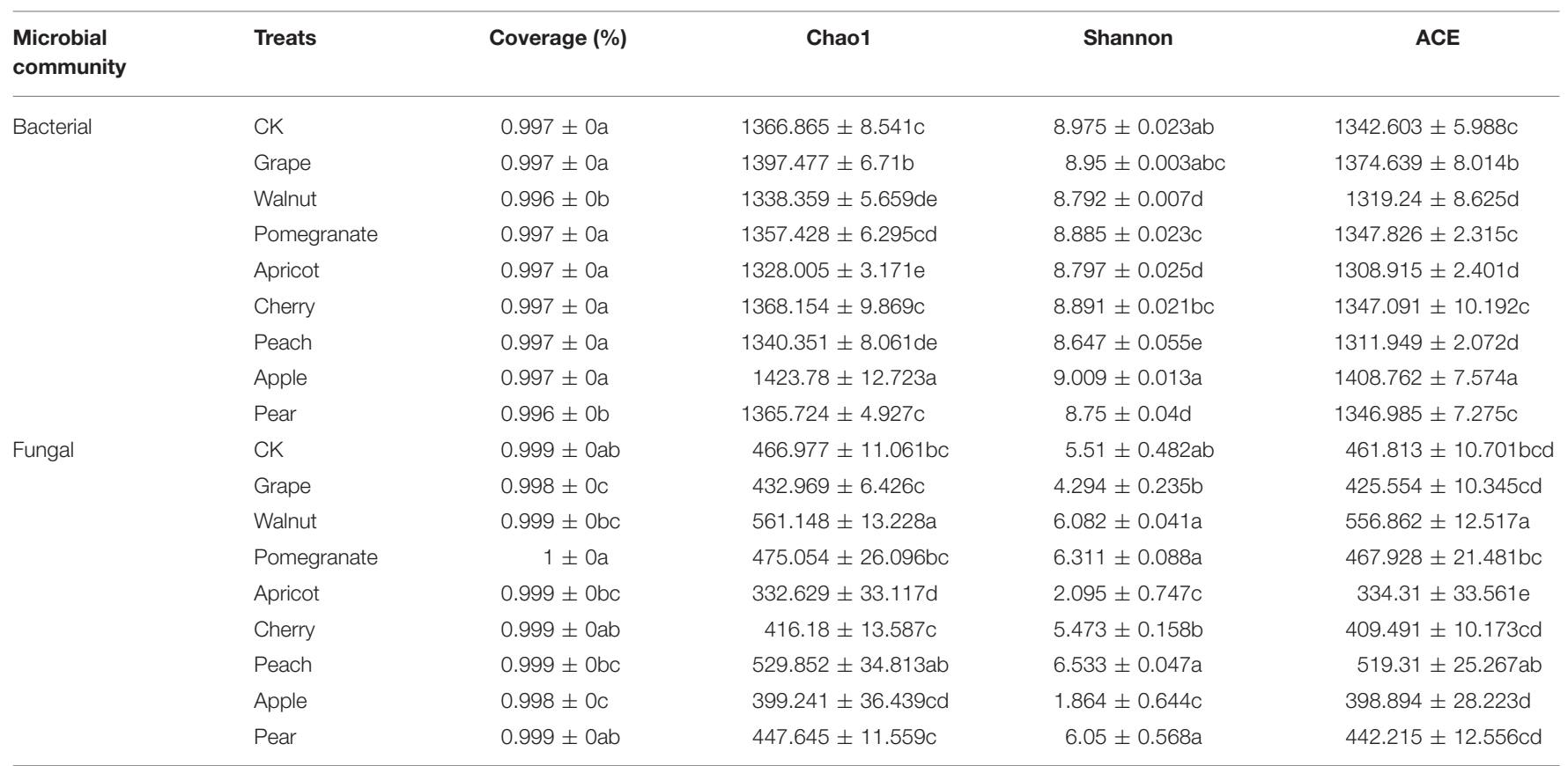

Values are means \pm SE. Suffixes in the same row indicate statistical significance at $p<0.05$ using one-way analysis of variance with tree species as the factor.
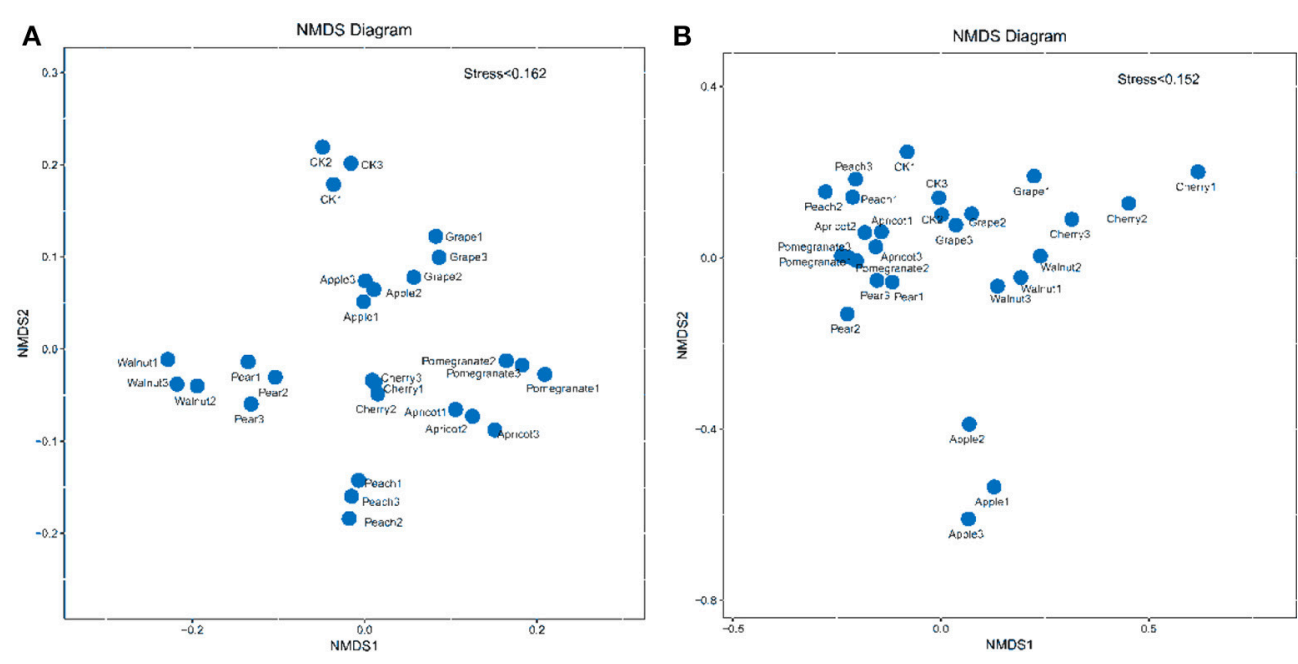

FIGURE 3 | Non-metric multidimensional scaling (NMDS) plots of bacterial (A) and fungal communities (B).

1,148 total OTUs obtained (Figure 4C). Similar to the bacterial communities, each species of deciduous fruit tree had its own unique fungal taxa. The number of unique fungal taxa was greater in the control and pear soils compared to the other soil samples, corresponding to 4.18 and $3.57 \%$ of the OTUs detected, respectively. In addition, $25,19,13$, and 11 OTUs $(2.18,1.66$, 1.13 , and $0.96 \%$ ) were only detected in the pomegranate, grape, apricot and peach rhizospheres, respectively. The Venn diagram revealed that significantly fewer core taxa were shared by all nine communities, and more unique taxa were present in the fungal communities.
A heatmap of bacterial and fungal community composition based on the relative abundances of genera in the rhizospheres of various deciduous fruit trees are shown in Figures 4B,D. The microbial communities showed noticeable and significant differences among the rhizospheres of various deciduous fruit tree species. In the bacterial communities, $R B 41$, Ambiguous_taxa, Sphingomonas, and H16 had high relative abundances in all communities, and there was no significant difference among communities. However, the distribution of other bacterial genera in the nine communities varied significantly. Compared to bacterial communities, the fungal 


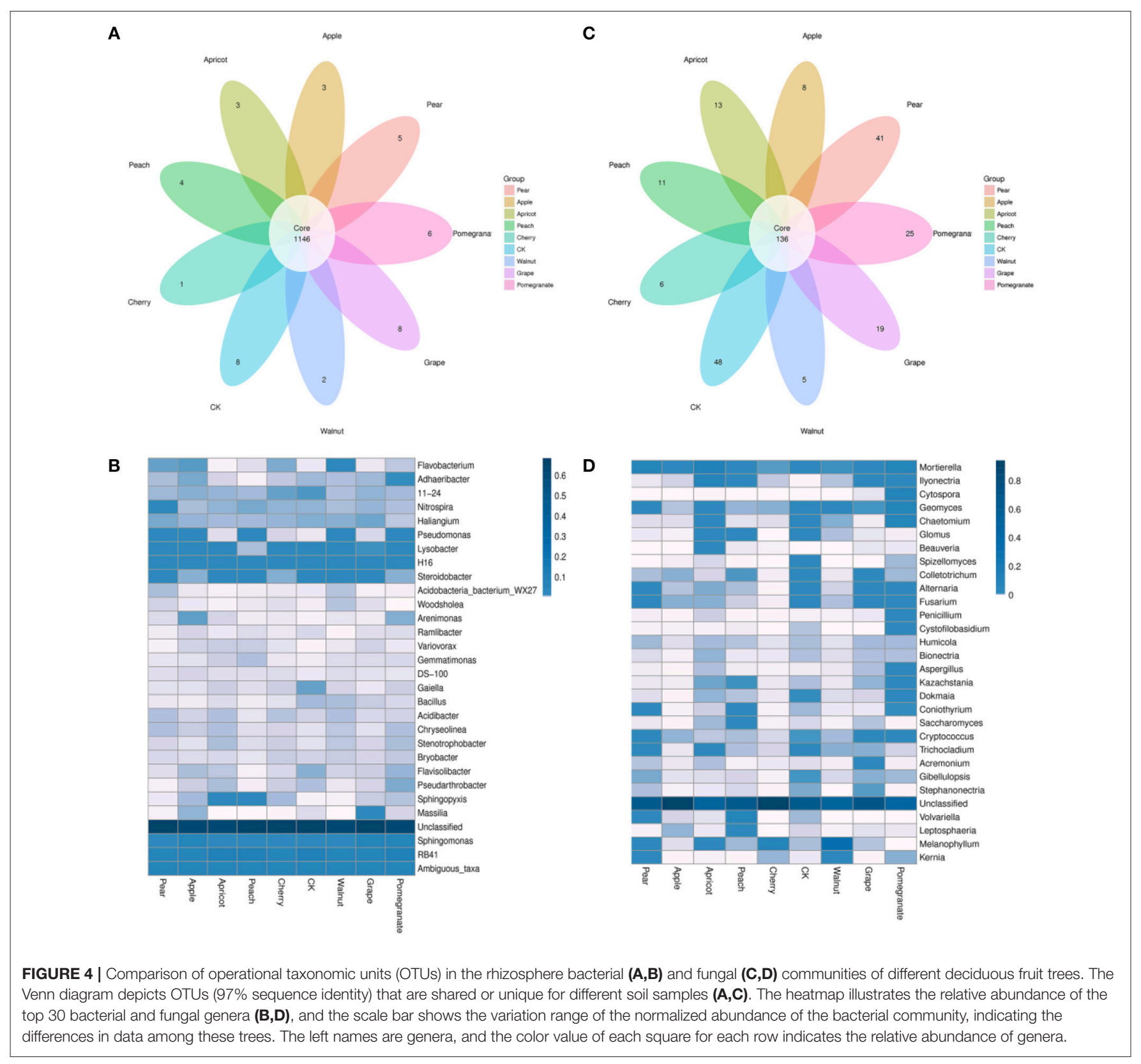

communities showed more significant differences among the nine samples.

The bacterial OTUs were classified into 31 phyla. Acidobacteria was the most abundant (36.08\% of all sequences), followed by Proteobacteria (33.89\%), Gemmatimonadetes (8.6\%), and Bacteroidetes (7.85\%) across our dataset. Phylogenetic characterization of $16 \mathrm{~S}$ rRNA gene amplicon sequencing data at lower taxonomic levels revealed significant differences in the number of phyla present among fruit tree species (Figure 5). We observed greater relative abundances of Actinobacteria and Nitrospirae, and a lower relative abundance of Proteobacteria, in the control samples compared to the deciduous fruit tree samples (Figures 5A,B,F). Among the eight kinds of fruit trees, the relative abundance of Acidobacteria was greatest and that of Proteobacteria was lowest in the cherry soil. In addition, the relative abundance of Bacteroidetes was greater, and the relative abundances of Gemmatimonadetes and Nitrospirae were lower, in the pomegranate soil than in the soils from other trees.

Fungal OTUs were classified into 12 phyla. The deciduous fruit tree soils were dominated by Ascomycota $32.33 \%$ of sequences) and Basidiomycota (11.21\%), with OTUs assigned to Zygomycota (5.26\%) and Glomeromycota (1.01\%) also present. Similar to the relative abundances of bacterial phyla, the fungal phyla in the soil differed notably among the eight species of deciduous fruit trees. In addition, the relative abundances of fungi in the control and fruit tree soils did not differ 


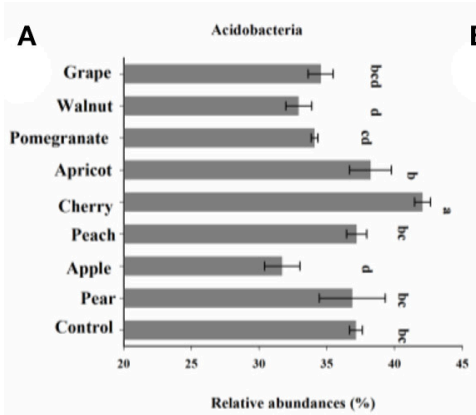

B
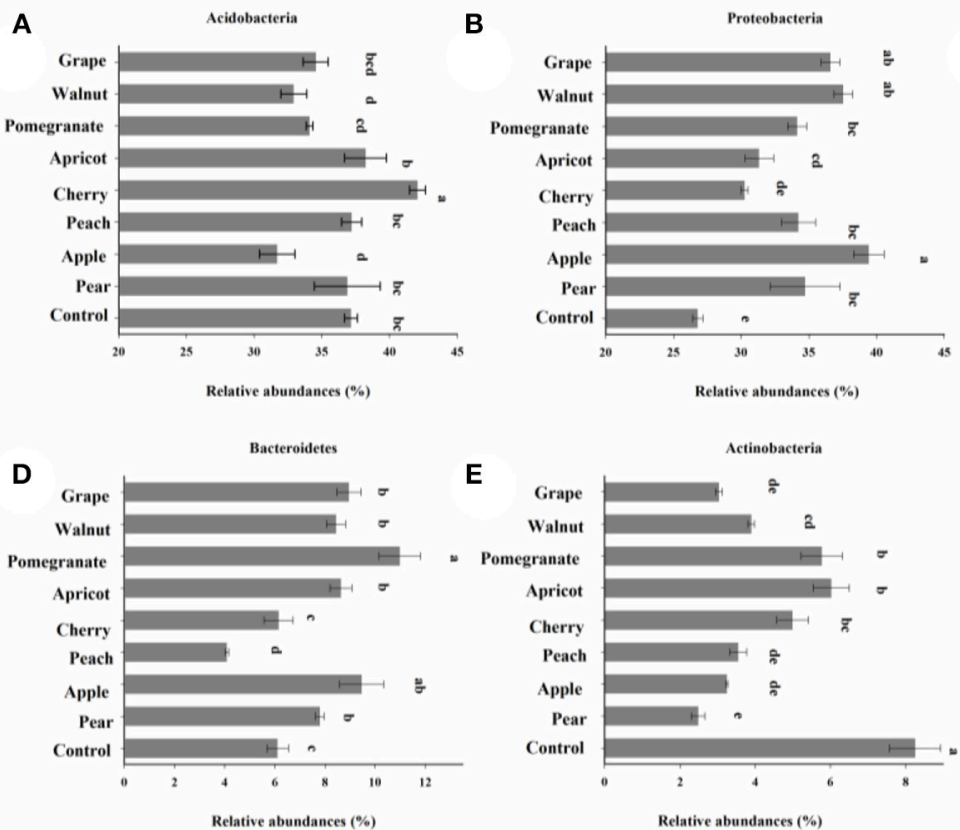

Relative abundances $(\%)$

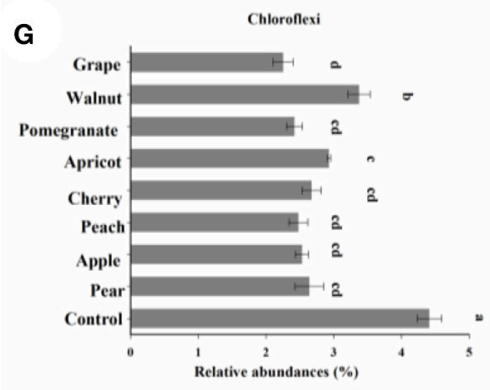

H
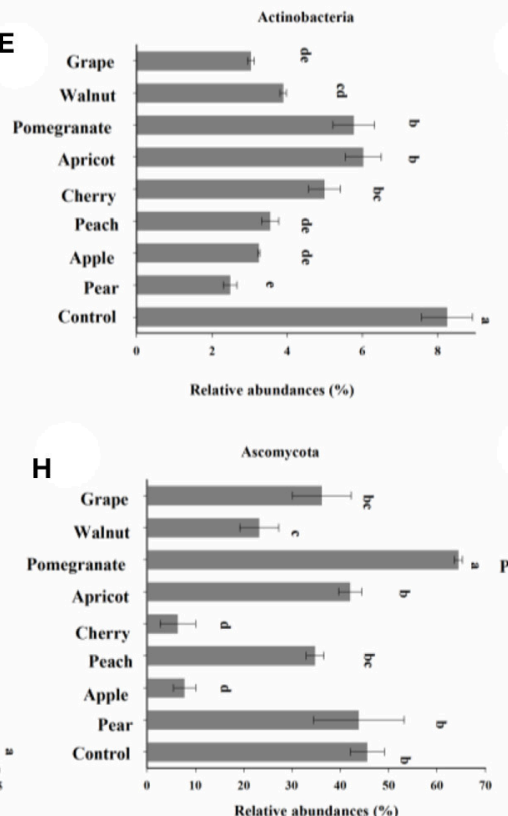
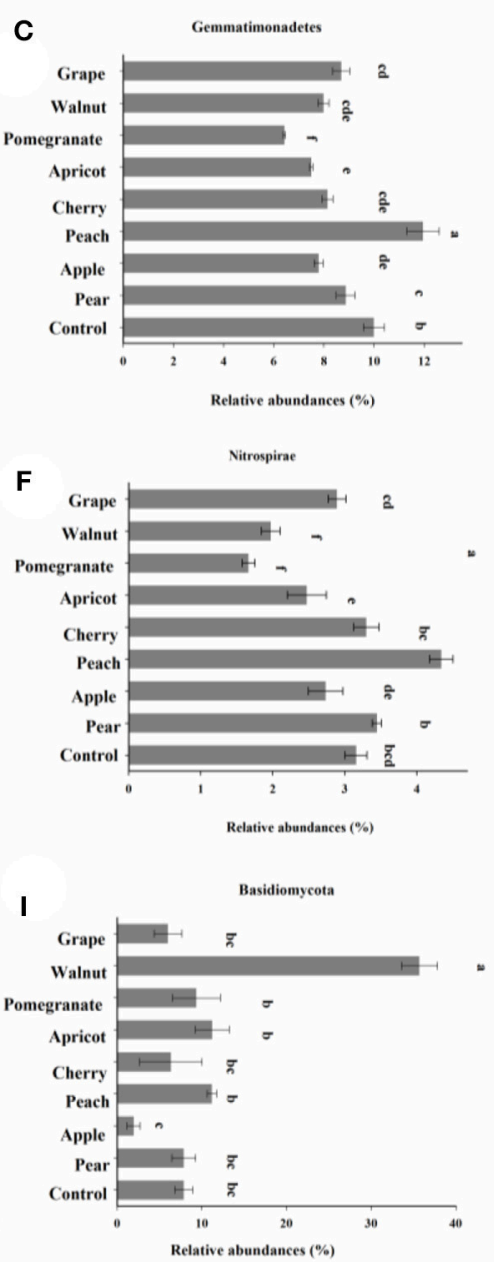
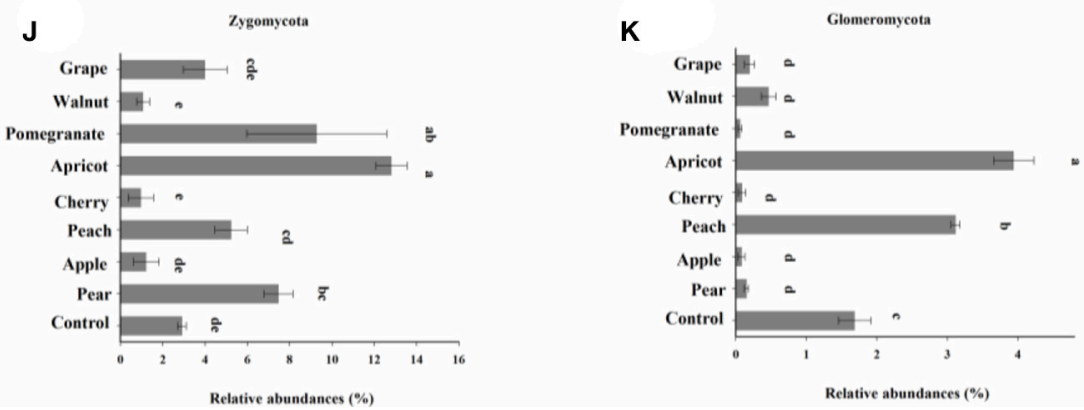

FIGURE 5 | Relative abundances (\%) of bacterial phyla (A-G; >1.0\% of total composition in all samples) and fungal phyla (H-K; $>0.01 \%$ of total composition in all sample). Values are means \pm SE. Suffixes in the same row indicate statistical significance at $p<0.05$ using one-way analysis of variance with tree species as the factor.

significantly. Among the tree species, the relative abundances of four fungal phyla in the cherry rhizosphere were all low, especially Ascomycota and Zygomycota. Compared to other fruits, Ascomycota (excluding cherry) and Basidiomycota had low relative abundances in the apple soil. Ascomycota and Basidiomycota were significantly higher in abundance in the pomegranate and walnut soils, respectively, compared to the other tree species. Furthermore, the relative abundances of Zygomycota and Glomeromycota were highest in the apricot soil.

To clarify differences in the rhizosphere microenvironment among the eight deciduous fruit trees, PCA analysis (Figure S1) of soil parameters was performed. The results showed that each 
fruit tree species has its own cluster, indicating that soil available nutrient content, soil enzyme activity and major microbial genera were significantly affected by tree species. Walnut samples clustered far away from other samples, indicating that the rhizosphere microenvironment of walnut trees differed markedly from that of the others. The apricot, cherry, and peach clusters were close, as were the apple and pear clusters. Interestingly, apricots, cherries, and peaches belong to Prunoideae, while apples and pears belong to Maloideae. This finding suggested that the rhizosphere microenvironment might be related to the subfamily of fruit trees among these deciduous fruit tree species.

\section{Relationships Between Soil Microbial Communities and Environmental Factors}

Redundancy analysis (RDA; Figure 6) was conducted to investigate the relationships among environmental factors, bacterial communities, CLPP, and soil enzymes. RDA1 and RDA2 accounted for $84.7 \%$ of the total variation (Figure 6). These four axes were considered significant variables and together explained $90.9 \%$ of the total variation, of which the first and second axis explained 62.5 and $22.2 \%$, respectively. RDA analysis showed that ammonia nitrogen content, soil $\mathrm{pH}$ and invertase activity were closely related to the soil microbial community. The Pearson correlation coefficients between relative abundances of bacterial and fungal genera and environmental factors showed that the soil microbial utilization of the six C sources, nitrate nitrogen content, and invertase activity were negatively correlated with Ambiguous and Alternaria, but positively correlated with $\mathrm{pH}$ (Table 4).

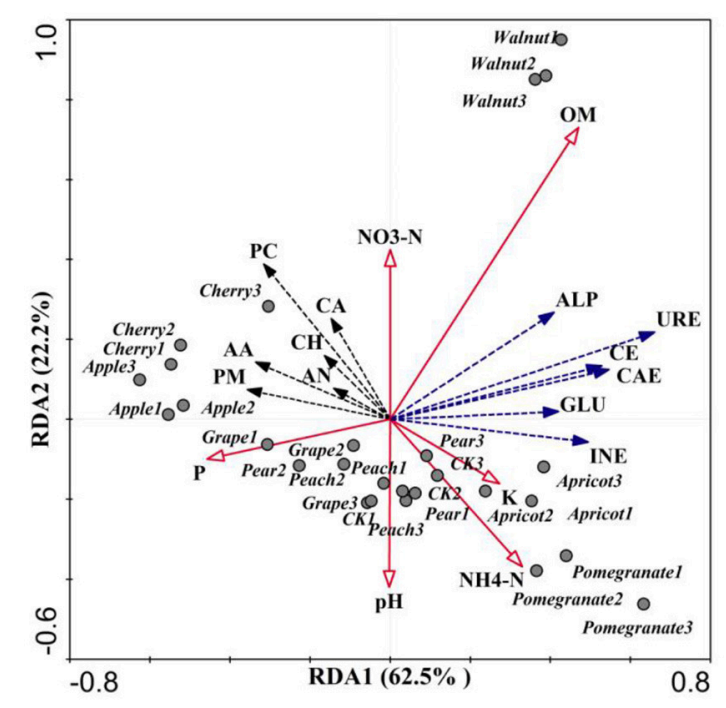

FIGURE 6 | Redundancy analysis (RDA) of microbial communities using bacterial and fungal genus relative abundances. Community-level physiological profile (URE, urease; CAE, catalase; GLU, $\beta$-glucosidase; CE, cellulase; INE, invertase; ALP, alkaline phosphatase) of six types of substrates (PM, polymers; $\mathrm{CH}$, carbohydrate; $\mathrm{PC}$, phenolic compounds; $\mathrm{CA}$, carboxylic acids; $\mathrm{AA}$, amino acids; AN, amines) and mineral element content (OM, organic matter; $\mathrm{K}$, available potassium; P, available phosphorus).
The ammonia nitrogen content was positively correlated with C source utilization and negatively correlated with Ambiguous, Lysobacter, Nitrospira, Alternaria, Fusarium, and Colletotrichum abundance. Invertase activity was positively correlated with $\mathrm{CH}, \mathrm{CA}, \mathrm{AA}, \mathrm{AN}$, and $\mathrm{OM}$ content. Interestingly, invertase activity was closely related to the fungal community, exhibiting positive correlations with Mortierella, Geomyces, Lysobacter, and Chaetomium, and negative correlations with Alternaria, Fusarium, and Colletotrichum. In addition, Ambiguous had the most significant negative correlation with microbial $\mathrm{C}$ utilization.

\section{DISCUSSION}

The rhizosphere is essential not only for plant nutrition, health, and quality, but also for microbe-driven $\mathrm{C}$ sequestration, ecosystem function and nutrient cycling in terrestrial ecosystems (Berg and Smalla, 2009). In particular, for fruit trees, the biotic and abiotic characteristics of rhizosphere soil determine fruit quality and yield. Analysis of the physicochemical properties of rhizosphere soil along with the enzyme activities and microbial communities of soils among different species of deciduous fruit trees provides significant benefit for elucidating differences in the rhizosphere environments of various fruit trees, and may facilitate increased fruit production and sustainable agricultural development.

\section{Effects of Tree Species on Soil Physicochemical Properties and Enzyme Activities}

The various tree species tested in this study had significant impacts on soil physicochemical properties, soil enzyme activity and substrate quality. Ding et al. (2011) revealed that soil $\mathrm{pH}$, a factor that affects crop growth, not only influenced various soil enzyme activities, but also significantly affected the effectiveness of the substrate. RDA analysis showed that soil $\mathrm{pH}$ was negatively correlated with the rhizosphere microbial community's utilization of six C substrates, as well as the $\mathrm{OM}$ content and ammonia nitrogen content (Figure 6). Rousk et al. (2010) proposed that soil microbial communities were related to the soil $\mathrm{pH}$, and found that bacterial communities are more sensitive to $\mathrm{pH}$ than fungal communities. In addition, rhizosphere soil $\mathrm{pH}$ decreased significantly with the planting of fruit trees (Table 1), which can be attributed to the large amount of organic acids secreted by fruit roots. Augusto et al. also found that tree species promoted greater soil acidification and decreased pH in European forests (Augusto et al., 2002). Interestingly, the secretion of organic acids not only decreases the $\mathrm{pH}$ of the rhizosphere soil, but can also recruit microorganisms, leading to changes in soil microbial communities and the formation of $\mathrm{OM}$ and ammonia nitrogen (Haichar et al., 2008; Dennis et al., 2010). Because soil $\mathrm{pH}$ is a critical parameter that influences the bioavailability of many toxic and nutritive elements, as well as the physiology of the roots and the rhizosphere microbial community, rooted-mediated changes in $\mathrm{pH}$ are of ecological importance (Hinsinger et al., 2003). 


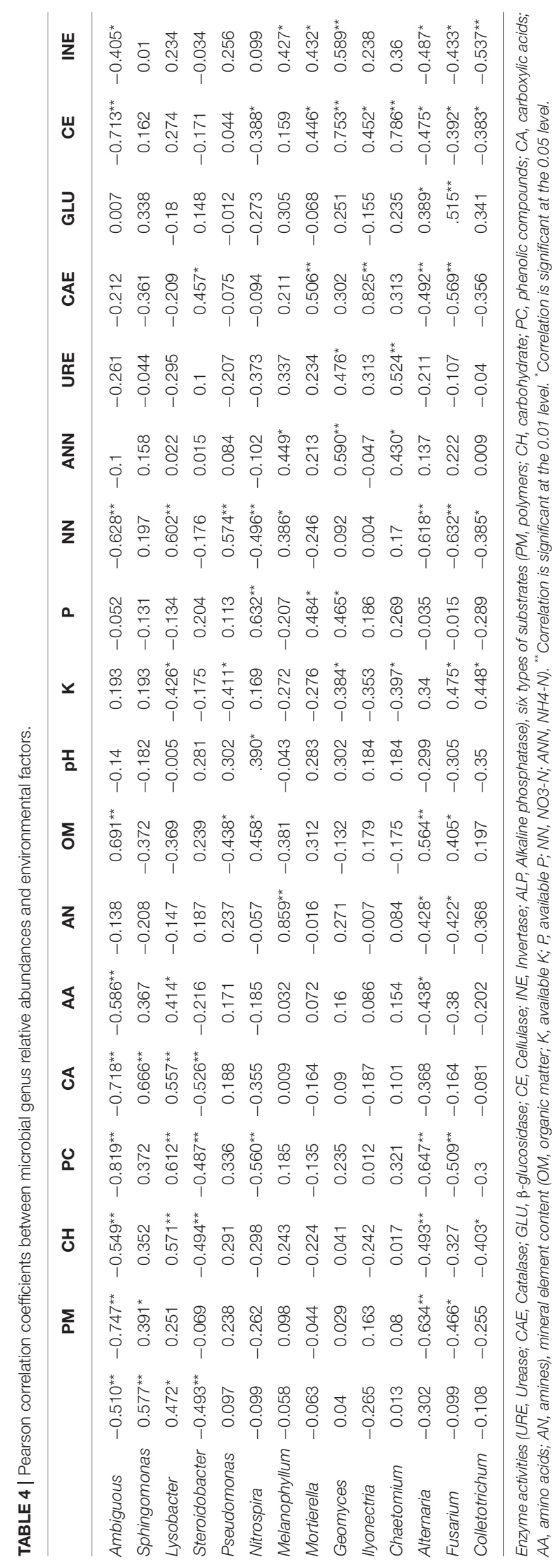

Moreover, the rhizosphere is dynamic and active, with newly generated $\mathrm{C}$, derived from root secretions, and ancient $\mathrm{C}$ in SOM both available for microbial growth (Haichar et al., 2008).

Tree species have multiple effects on rhizosphere soil through many mechanisms, including the rates of nutrient input, output, and cycling (Augusto et al., 2002; Knops et al., 2002). Given the gradual increase of the area planted with fruit trees, it is now essential to clarify soil nutrient cycling in various species of fruit trees. In terms of soil biology and ecology, understanding available nutrients in soil and their interactions with rhizospheric processes is an important subject. The contents of soil nutrients (except for available $\mathrm{P}$ ) in the rhizosphere increased in the presence of fruit trees in this study (Table 1). A study on plant-soil interactions by Ehrenfeld (2003) showed that the introduction of a new plant species has the potential to alter many components of the water, $\mathrm{C}, \mathrm{N}$, and other cycles in an ecosystem, ultimately resulting in an increase in the available mineral content of the rhizosphere soil. In addition, the mineral contents of the rhizospheres of different fruit trees differed significantly. This effect may be related to fruit tree species and the size of the fruit tree. Weand et al. (2010) revealed that $\mathrm{N}$ retention and soil $\mathrm{C}$ storage in a forest are influenced by the associated soil microbes and tree species. Further, microbial community structure and function data at the tree-species level will be required for prediction of long-term $\mathrm{C}$ and $\mathrm{N}$ dynamics (Weand et al., 2010). Moreover, evidence from Knops et al. (2002) showed that plant species could strongly influence ecosystem $\mathrm{N}$ cycling. Therefore, the effect of tree species is exerted via impacts on $\mathrm{N}$ inputs and losses, rather than solely by differences in plant quantity and quality. Soil $\mathrm{N}$ is closely related to OM. Furthermore, root exudates such as citric acid and malic acid can increase soil nutrient levels and improve the soil environment (Hou et al., 2018). Additionally, plant species have large impacts on the composition and activity of the microbial communities in rhizospheric soils, and this influence has the potential to cause differences in available nutrient contents. Our results indicated that the magnitude of the rhizosphere effect on SOM accumulation varied dramatically, from 102.6 to $201.2 \%$ of the control, and was mainly affected by tree species (Table 1). Knops et al. (2002) also supported the hypothesis that $\mathrm{N}$ released from SOM could be incorporated by microbes. However, they found no correlation between SOM and N using RDA (Figure 1). Cheng (2009) revealed that rhizospheric enhancement of soil C mineralization in planted treatments did not result in a proportional increase in net $\mathrm{N}$ mineralization, suggesting a possible decoupling of $\mathrm{C}$ cycling and $\mathrm{N}$ cycling in the rhizosphere. Hence, $\mathrm{C}$ cycling and $\mathrm{N}$ cycling in the rhizosphere of eight fruit trees appeared to be decoupled. However, urease, an important enzyme involved in soil $\mathrm{N}$ cycling, was positively correlated with SOM, showing that the $\mathrm{C}$ and $\mathrm{N}$ cycles are coupled (Figure 5). This result may be attributed to limited $\mathrm{N}$ content in the soil, which leads to greater immobilization and less mineral $\mathrm{N}$ availability in some rhizosphere environments.

Soil enzymes, which are related to OM dynamics and mineral nutrient cycling in the soil, are considered sensitive 
early indicators of alterations in soil quality (Puglisi et al., 2006; Zhang et al., 2011; Paz-Ferreiro and Fu, 2016). The RDA revealed that the activities of cellulase and invertase were positively correlated with OM content (Figure 6). Alvarenga et al. (2008) found that cellulase and invertase are highly sensitive to substrate availability and are involved in the decomposition of $\mathrm{OM}$ and the release of reducing sugars as end products of the $\mathrm{C}$ cycle (Zhang et al., 2011). Phosphatases provide an excellent indicator of the organic $\mathrm{P}$ mineralization potential and biological activity in soils (Dick and Tabatabai, 1993; Kotroczó et al., 2014). Alkaline phosphatase activity was positively correlated with Melanophyllum, Mortierella, and Geomyces, and negatively correlated with Alternaria, Fusarium, and Colletotrichum (Table 4). Urease activity is often used as an index of $\mathrm{N}$ mineralization, as it is involved in catalyzing the hydrolysis of organic $\mathrm{N}$ to inorganic $\mathrm{N}$ in the soil (Sardans et al., 2008). RDA analysis revealed that urease activity was positively correlated with SOM. Similarly, Myers et al. found that urease activity is strongly correlated with the SOM content (Myers and McGarity, 1968; Dalal, 1975; Bremner and Mulvaney, 1978; Roscoe et al., 2000). Furthermore, catalases are primarily associated with soil respiration and microbial activity, and they reflect the intensity of soil microbial processes (Haichar et al., 2008; Yu et al., 2016). Catalase activity was positively correlated with Geomyces and Chaetomium abundances (Table 4). As shown in Table 2, soil enzyme activity showed significant differences among fruit tree species. Chodak and Niklinska (2010) revealed that the activity of acid phosphomonoesterase was not affected by tree species, while dehydrogenase and urease activities were significantly affected by tree species and were greatest under pine (Chodak and Niklinska, 2010). Brockett et al. (2012) found that enzyme profiles differed among forest types, and phenol oxidase and peroxidase activities differed from other enzyme activities in seven forest types (Brockett et al., 2012). Weand et al. (2010) illustrated that soil enzymes were not affected by tree species, but were significantly affected by fertilizer application.

\section{Effects of Tree Species on Microbial Communities}

Plants can influence rhizosphere microbial communities, which are essential to crop growth and yield (Kodama et al., 2011; Berendsen et al., 2012; Sugiyama et al., 2014). In this study, the rhizosphere microbial communities of different deciduous fruit trees grown for 5 years in the field were analyzed using PCR and Illumina sequencing to identify trends in the development of microbial community composition, and using the BIOLOG EcoPlate to construct CLPPs and clarify the rhizosphere soil environments of different deciduous fruit trees.

As a rapid screening method for detecting differences among different treatments, CLPP has been widely applied to characterization of microbial communities in numerous habitats, ranging from native soil to sewage sludge-amended soil and organic compost (Doran et al., 1996; Sharma et al., 1998; Insam and Goberna, 2004; Frac et al., 2012). Furthermore, this method has the potential to overcome the disadvantages of culture-based analyses and biochemical tests, and it is frequently employed to determine the effects of various environmental factors on soil properties based on the catabolic characteristics of microbial communities (Haack et al., 1995; Schutter and Dick, 2001; Preston-Mafham et al., 2002). In this study, Biolog substrate utilization assays revealed that the metabolic capabilities of peach rhizosphere soil were lower than those of other deciduous fruit tree soils (Figure 2). However, apple rhizosphere soil had the highest microbiological activity among the deciduous fruit trees investigated. This finding indicates that, given the same soil background, the metabolism of rhizosphere microbial communities around deciduous fruit trees differs 5 years after planting, which may be related to differences in the growth of tree roots, rhizosphere secretions and fertilizer requirements. However, further verification of these hypotheses is needed.

Soil microbial communities are the largest known reservoir of biological diversity in the world and are important for plant growth (Curtis et al., 2002; Torsvik et al., 2002; Gams, 2007; Buée et al., 2010; Berendsen et al., 2012). The rhizosphere microbiome, which is shaped by root secretions, can influence plants through genetic elements and interactions (Berendsen et al., 2012). Therefore, investigating the composition of the rhizosphere microbiome and its relationship with environmental parameters is essential. In this study, bacterial $\alpha$-diversity indices of apple soil were higher than those of other deciduous fruit tree soils, while those of walnut were relatively low (Table 3). Conversely, the fungal $\alpha$-diversity indices of the walnut soil were higher than those of other deciduous fruit tree soils, while those of the apple soil were relatively low. Moreover, the apricot soil had relatively low bacterial and fungal $\alpha$-diversity indices. Hence, significant differences were observed in rhizosphere microbial community diversity among the walnut, apple and apricot soils. Moreover, the microbial community results showed that the rhizosphere microbiome was significantly affected by tree species. Similar studies have indicated that each plant species was colonized by specific microbial populations, and that many plant diseasecausing organisms, including bacteria and fungi, have co-evolved with plants and exhibit high host specificity (Long, 2001; Berg and Smalla, 2009; Raaijmakers et al., 2009; Costa et al., 2010). Costa et al. (2010) revealed that plant species was a crucial factor in shaping the differentiation of actinobacterial communities in the strawberry rhizosphere from bulk soil. Similarly, according to the Venn diagram results in this study, each tree species had its own unique OTUs. The relative abundances of bacterial and fungal phyla showed that the composition of the rhizosphere microbial communities associated with the eight deciduous fruit trees differed significantly in terms of the nine dominant bacterial and fungal phyla. Furthermore, the composition of microbial communities in the rhizosphere soil of different deciduous fruit trees revealed that fungal communities have more unique taxa and less diversity than bacterial communities. Urbanová et al. (2015) also discovered that fungal communities were less diverse than bacterial communities, and showed a greater tendency to be tree-specific in a forest ecosystem. Hence, the effect of trees species on the composition of the microbial community was found to be especially strong for fungi. 


\section{Rhizosphere Microbes of Deciduous Fruit Trees Were Related to Soil Physicochemical Properties and Enzyme Activities}

Pearson correlation coefficients between the relative abundances of bacterial and fungal genera and environmental factors showed that soil microbial utilization of the six $\mathrm{C}$ sources, the nitrate nitrogen content and invertase activity were negatively correlated with Alternaria, but positively correlated with $\mathrm{pH}$ (Table 4). The Alternaria genus includes both plant-pathogenic and saprophytic species, which may affect crops in the field or result in harvest and postharvest decay of plant products (Logrieco et al., 2009; Dean et al., 2014). This genus can produce diverse secondary metabolites, including toxins (Montemurro and Visconti, 1992), and some of these metabolites are effective mycotoxins (e.g., alternariol, alternariol methyl ether, tenuazonic acid, etc.) with mutagenic and teratogenic properties (Liu et al., 1991; Dean et al., 2014). Therefore, Alternaria has the potential to inhibit the growth of other microbes or organisms, resulting in decreased metabolic capacity of the microbial community and invertase activity in the soil. Furthermore, the ammonia nitrogen content was negatively correlated with Lysobacter, Nitrospira, Alternaria, Fusarium, and Colletotrichum (Table 4). Nitrospira, a group of nitrite-oxidizing bacteria, are the most widespread nitrifiers in the environment (Lücker et al., 2010; Koch et al., 2015). Hence, Nitrospira had a strong negative correlation with the ammonia nitrogen content. Members of the genus Lysobacter are Gram-negative bacteria widely distributed in freshwater, soil and plant environments, and the genus owes its name to its lytic effects on other microorganisms (de Bruijn et al., 2015). Daft et al. suggested that the spectacular lytic capabilities of Lysobacter species suggest that they might play a critical role in the control of microbial populations in nature (Daft et al., 1975; Reichenbach, 2006). In addition, Lysobacter can synthesize new secondary metabolites, such as phenazine- $N$-oxide and myxin, which inhibit the growth of or destroy other microorganisms (Peterson et al., 1966; Weigele and Leimgruber, 1967). Fusaric acid is a secondary metabolite produced by certain species of Fusarium that can cause wilt disease in tomatoes, cotton, peas, bananas, watermelons, and other crops (Wood et al., 1972; Bacon et al., 1996; Watanabe et al., 2011). Invertase activity was positively correlated with $\mathrm{CH}, \mathrm{CA}, \mathrm{AA}, \mathrm{AN}$, and $\mathrm{OM}$ content in this study. In particular, invertase was closely related to the fungal community, showing positive correlations with Mortierella, Geomyces, Lysobacter, and Chaetomium, and negative correlations with Alternaria, Fusarium and Colletotrichum. Interestingly, Franke demonstrated that the genus Mortierella was the most abundant fungal genus showing a strongly positive correlation with plant growth (Franke-Whittle et al., 2015). Members of the genus Geomyces can form mycorrhizae with the roots of plants, such as alpine Ericales, allowing these plants to adapt to lownutrient environments (Dalpé et al., 1989). Members of the genus Chaetomium are considered a rich source of novel and bioactive secondary metabolites, with highly promising potential applications (Li et al., 2014), and most of these fungal metabolites exhibit antitumor, cytotoxic, antimalarial, enzyme-inhibitory, antibiotic activities, among others (Zhang et al., 2012). The genus Colletotrichum, the eighth most important phytopathogenic fungus in the world, is a large genus of Ascomycete fungi containing many species that cause anthracnose or blight in a wide range of important crop and ornamental plants (Bailey and Jeger, 1992; Perfect et al., 1999; Dean et al., 2012). Interestingly, in this study, Mortierella, Geomyces, Lysobacter, and Chaetomium were plant-beneficial microbes, while Alternaria, Fusarium, and Colletotrichum were categorized as plant pathogens. These results showed that invertase activity was not only closely related to the metabolic activities of the rhizosphere microbial community, but also positively correlated with plant-beneficial microbes such as Mortierella. Invertase activity was negatively correlated with pathogenic microbes such as Fusarium, among the main fungal genera observed. Therefore, soil invertase activity, an important indicator of soil quality, is closely related to many soil parameters and has the potential to indicate the rhizosphere soil state of deciduous fruit trees in northern China.

\section{Further Research: Rhizosphere Microbes Secrete Soil Enzymes to Reach Their Catalytic Potential in the Rhizosphere}

The catalytic potential of rhizosphere microbes is mainly attained through secretion of various soil enzymes involved in soil nutrient cycling and resource exchange (Aon and Colaneri, 2001; Cardon and Gage, 2006; Robertson and Groffman, 2007; Mohammadi, 2012). In this study, six soil enzymes were chosen to clarify the relationship between soil enzyme activity, available nutrient content, and the dominant genera of soil microbes. Our results indicated that invertase and urease are closely related to soil available nutrient content and major microbial genera (Table 4 and Table S4), and thus may play a major role in the rhizosphere soil environment. To further elucidate the catalytic potential of microbes in the rhizosphere microenvironment, research on processes such as $\mathrm{N}$ fixation, phosphate solubilization, and metal quenching potential will be conducted in the future.

\section{CONCLUSION}

This study demonstrated that fruit tree species had significant impacts on soil physicochemical properties, soil enzyme activities, and the soil microbial community, suggesting that the microenvironment of the rhizosphere soil was shaped by the presence of eight common deciduous fruit trees and was closely related to soil microbes in northern China. The correlations among rhizosphere parameters showed that $\mathrm{pH}$ was negatively correlated with the utilization of the six $\mathrm{C}$ sources in the rhizosphere soil ecosystem of the deciduous fruit trees, indicating that soil $\mathrm{pH}$ has the ability to affect the metabolism of microbial communities. Correlations between the soil ammonium nitrogen content and various indicators were also observed, indicating that the sensitivity of soil ammonium nitrogen to environmental changes may allow it to be used as an indicator. The SOM and Geomyces were positively correlated with urease, catalase, 
invertase and alkaline phosphatase activities, revealing that $\mathrm{OM}$ and Geomyces may have close relationships with soil enzymes, and could have the potential to enhance soil enzyme activity. Invertase activity was not only closely related to the metabolic activities of the rhizosphere microbial community, but was also positively related to plant-beneficial microbes such as Mortierella and negatively correlated with pathogenic microbes such as Fusarium, among the main fungal genera.

\section{AUTHOR CONTRIBUTIONS}

PS, WS, and GW contributed to the conceptualization of the study. WS contributed to the data curation and formal analysis. ZW and GW contributed to the funding acquisition. WS, HY, and $\mathrm{XY}$ contributed to the investigation. WS and XY contributed to the methodology. PS and WS contributed to the project administration and wrote the original draft of the manuscript. PS and GW contributed to the resources. WS and HY contributed to the software. PS, WS, HY, XY, DG, XQ, ZW, and GW contributed to the supervision and visualization. PS and GW contributed to the validation. WS, PS, and HY wrote, reviewed and edited the manuscript.

\section{REFERENCES}

Alvarenga, P., Palma, P., Gonçalves, A. P., Baião, N., Fernandes, R. M., Varennes, A. D., et al. (2008). Assessment of chemical, biochemical and ecotoxicological aspects in a mine soil amended with sludge of either urban or industrial origin. Chemosphere 72, 1774-1781. doi: 10.1016/j.chemosphere.2008.04.042

Aon, M. A., and Colaneri, A. C. (2001). II. Temporal and spatial evolution of enzymatic activities and physico-chemical properties in an agricultural soil. Appl. Soil Ecol. 18, 255-270. doi: 10.1016/S0929-1393(01)00161-5

Augusto, L., Ranger, J., Dan, B., and Rothe, A. (2002). Impact of several common tree species of european temperate forests on soil fertility. Ann. Forest Sci. 59, 233-253. doi: 10.1051/forest:2002020

Babu, A. N., Jogaiah, S., Ito, S. I., Nagaraj, A. K., and Tran, L. S. P. (2015). Improvement of growth, fruit weight and early blight disease protection of tomato plants by rhizosphere bacteria is correlated with their beneficial traits and induced biosynthesis of antioxidant peroxidase and polyphenol oxidase. Plant Sci. 231, 62-73. doi: 10.1016/j.plantsci.2014.11.006

Bacon, C. W., Porter, J. K., Norred, W. P., and Leslie, J. F. (1996). Production of fusaric acid by Fusarium species. Appl. Environ. Microbiol. 62, 4039-4043.

Bailey, J. A., and Jeger, M. J. (1992). Colletotrichum: biology, pathology and control. Mycologia 85, 879. doi: 10.2307/3760628

Bais, H. P., Weir, T. L., Perry, L. G., Gilroy, S., and Vivanco, J. M. (2006). The role of root exudates in rhizosphere interactions with plants and other organisms. Annu. Rev. Plant Biol., 57, 233-266. doi: 10.1146/annurev.arplant.57.032905.105159

Berendsen, R. L., Pieterse, C. M. ., and Bakker, P. A. (2012). The rhizosphere microbiome and plant health. Trends Plant Sci. 17, 478-486. doi: 10.1016/j.tplants.2012.04.001

Berg, G., and Smalla, K. (2009). Plant species and soil type cooperatively shape the structure and function of microbial communities in the rhizosphere. FEMS Microbiol. Ecol. 68, 1-13. doi: 10.1111/j.1574-6941.2009.00654.x

Bottini, R., Cassán, F., and Piccoli, P. (2004). Gibberellin production by bacteria and its involvement in plant growth promotion and yield increase. Appl. Microbiol. Biotechnol. 65, 497-503. doi: 10.1007/s00253-004-1696-1

Bremner, J. M., and Mulvaney, R. L. (1978). "Urease activity in soil," in Soil Enzymes, ed R. G. Burns (New York, NY: Academic Press), 149-196.

Brockett, B. F. T., Prescott, C. E., and Grayston, S. J. (2012). Soil moisture is the major factor influencing microbial community structure and enzyme activities

\section{ACKNOWLEDGMENTS}

Financial support was provided by the Agricultural Science and Technology Innovation Program (ASTIP) of the Chinese Academy of Agricultural Sciences (CAAS-ASTIP-2018-ZFRI) and Major Science and Technology Project in Henan Province (151100110900).

\section{SUPPLEMENTARY MATERIAL}

The Supplementary Material for this article can be found online at: https://www.frontiersin.org/articles/10.3389/fmicb. 2018.03147/full\#supplementary-material

Table S1 | Sequencing data details of bacterial communities.

Table S2 | Sequencing data details of fungal communities.

Table S3 | Rhizosphere soil trace element content of different deciduous fruit trees.

Table S4 | Pearson correlation coefficients between of soil enzymes and environmental factors.

Figure S1 | Principal component analysis (PCA) of rhizosphere soil parameters (including soil available nutrient content, soil enzyme activity, and major microbial genus), showing differences among eight deciduous fruit trees. across seven biogeoclimatic zones in western canada. Soil Biol. Biochem. 44, 9-20. doi: 10.1016/j.soilbio.2011.09.003

Buée, M., Reich, M., Murat, C., Morin, E., Nilsson, R. H., Uroz, S., et al. (2010). 454 pyrosequencing analyses of forest soils reveal an unexpectedly high fungal diversity. N. Phytol. 184, 449-456. doi: 10.1111/ j.1469-8137. (2009). 03003.x

Cardon, Z. G., and Gage, D. J. (2006). Resource exchange in the rhizosphere: molecular tools and the microbial perspective. Annu. Rev. Ecol. Evol. Syst. 37, 459-488. doi: 10.1146/annurev.ecolsys.37.091305.110207

Chen, Y. T., Wang, Y., and Yeh, K. C. (2017). Role of root exudates in metal acquisition and tolerance. Curr. Opin. Plant Biol. 39, 66-72. doi: 10.1016/ j.pbi.2017.06.004

Cheng, W. (2009). Rhizosphere priming effect: its functional relationships with microbial turnover, evapotranspiration, and c-n budgets. Soil Biol. Biochem. 41, 1795-1801. doi: 10.1016/j.soilbio.2008.04.018

Chodak, M., and Niklinska, M. (2010). Effect of texture and tree species on microbial properties of mine soils. Appl. Soil Ecol. 46, 268-275. doi: 10.1016/j.apsoil.2010.08.002

Choi, K. H., and Dobbs, F. C. (1999). Comparison of two kinds of Biolog microplates (GN and ECO) in their ability to distinguish among aquatic microbial communities. J. Microbiol. Methods 36, 203-213. doi: 10.1016/S0167-7012(99)00034-2

Costa, R., Götz, M., Mrotzek, N., Lottmann, J., Berg, G., and Smalla, K. (2010). Effects of site and plant species on rhizosphere community structure as revealed by molecular analysis of microbial guilds. FEMS Microbiol. Ecol. 56, 236-249. doi: 10.1111/j.1574-6941.2005.00026.x

Curtis, T. P., Sloan, W. T., and Scannell, J. W. (2002). Estimating prokaryotic diversity and its limits. Proc. Natl. Acad. Sci. U.S.A. 99, 10494-10499. doi: 10.1073/pnas.142680199

Daft, M. J., McCord, S. B., and Stewart, W. D. P. (1975). Ecological studies on algal-lysing bacteria in fresh waters. Freshw. Biol. 5, 577-596. doi: 10.1111/j.1365-2427.1975.tb00157.x

Dalal, R. C. (1975). Urease activity in some trinidad soils. Soil Biol. Biochem. 7, 5-8. doi: 10.1016/0038-0717(75)90022-X

Dalpé, Y., Litton, W., and Sigler, L. (1989). Scytalidium vaccinii sp. nov., an ericoid endophyte of Vaccinium angustifolium roots. Mycotaxon 35, 371-377.

de Bruijn, I. ., Cheng, X., de Jager, V. , Expósito, R. G., Watrous, J., Patel, N., et al. (2015). Comparative genomics and metabolic profiling of the genus lysobacter. BMC Genomics 16:991. doi: 10.1186/s12864-015-2191-z 
Dean, R., van Kan, J. A., Pretorius, Z. A., Hammond-Kosack, K. E., di Pietro, A. D., Spanu, P. D., et al. (2012). The top 10 fungal pathogens in molecular plant pathology. IMA Fungus 13, 804-804. doi: 10.1111/j.1364-3703.2011. 00783.x

Dean, R. A., Lichens-Park, A., and Kole, C. (2014). "Alternaria comparative genomics: the secret life of rots" in Genomics of Plant-Associated Fungi and Oomycetes: Dicot Pathogens, eds H. X. Dang and C. B. Lawrence (Berlin: Springer), 45-64. doi: 10.1007/978-3-662-44056-8

Defago, G., Berling, C. H., Burger, U., Haas, D., Kahr, G., Keel, C., et al. (1990). "Suppression of black root rot of tobacco and other root diseases by strains of Pseudomonas fluorescens: potential applications and mechanisms," in Biological Control of Soil-Borne Plant Pathogens (Wallingford: CAB International), 93-108.

Dennis, P. G., Miller, A. J., and Hirsch, P. R. (2010). Are root exudates more important than other sources of rhizodeposits in structuring rhizosphere bacterial communities? FEMS Microbiol. Ecol. 72, 313-327. doi: 10.1111/j.1574-6941.2010.00860.x

Dick, W. A., and Tabatabai, M. A. (1993). "Significance and potential uses of soil enzymes," in Soil Microbial Ecology: Application in Agricultural and Environmental Management, ed F. B Metting (New York, NY: Marcel Dekker), 95-125.

Ding, X., Fu, L., Liu, C., Chen, F., Hoffland, E., Shen, J., et al. (2011). Positive feedback between acidification and organic phosphate mineralization in the rhizosphere of maize (zea mays, 1.). Plant and Soil, 349, 13-24. doi: 10.1007/s11104-011-0783-1

Doran, J. W., Sarrantonio, M., and Liebig, M. A. (1996). Soil health and sustainability. Advances in Agronomy, 56, 1-54. doi: 10.1016/S0065-2113(08)60178-9

Egamberdieva, D., Kamilova, F., Validov, S., Gafurova, L., Kucharova, Z., and Lugtenberg, B. (2010). High incidence of plant growth-stimulating bacteria associated with the rhizosphere of wheat grown on salinated soil in uzbekistan. Environ. Microbiol. 10, 1-9. doi: 10.1111/j.1462-2920.2007.01424.x

Ehrenfeld, J. G. (2003). Effects of exotic plant invasions on soil nutrient cycling processes. Ecosystems 6, 503-523. doi: 10.1007/s10021-002-0151-3

Eivazi, F., and Tabatabai, M. A. (1988). Glucosidases and galactosidases in soils. Soil Biol. Biochem. 20, 601-606. doi: 10.1016/0038-0717(88)90141-1

Feng, J., Liu, J., and Huo, X. (2014). Production and trade forecast analysis of world main fresh deciduous fruit in its producing country. North. Hortic. 4, 195-202.

Frac, M., Oszust, K., and Lipiec, J. (2012). Community level physiological profiles (CLPP), characterization and microbial activity of soil amended with dairy sewage sludge. Sensors 12, 3253-3268. doi:10.3390/s120303253

Franke-Whittle, I. H., Manici, L. M., Insam, H., and Stres, B. (2015). Rhizosphere bacteria and fungi associated with plant growth in soils of three replanted apple orchards. Plant Soil 395, 317-333. doi: 10.1007/s11104-015-2562-x

Gams, W. (2007). Biodiversity of soil-inhabiting fungi. Biodivers. Conserv. 16, 69-72. doi: 10.1007/s10531-006-9121-y

Guan, S. Y. (1986). Soil Enzymes and Their Research Methods (in Chinese). Beijing: Agricultural Press.

Guanghua, W., Junjie, L., Xiaoning, Q., Jian, J., Yang, W., and Xiaobing, L. (2008). Effects of fertilization on bacterial community structure and function in a black soil of Dehui region estimated by Biolog and PCR-DGGE methods. Acta Ecol. Sin. 28, 220-226. doi: 10.1016/S1872-2032(08)60023-2

Haack, S. K., Garchow, H., Klug, M. J., and Forney, L. J. (1995). Analysis of factors affecting the accuracy, reproducibility, and interpretation of microbial community carbon source utilization patterns. Appl. Environ. Microbiol. 61, 1458-1468.

Haichar, F. Z., Marol, C., Berge, O., Rangel-Castro, J. I., Prosser, J. I., Balesdent, J., et al. (2008). Plant host habitat and root exudates shape soil bacterial community structure. ISME J. 2, 1221-1230. doi: 10.1038/ismej.2008.80

Hinsinger, P., Plassard, C., Tang, C., and Jaillard, B. (2003). Origins of rootmediated $\mathrm{pH}$ changes in the rhizosphere and their responses to environmental constraints: a review. Plant Soil 248, 43-59. doi: 10.1023/A:1022371 130939

Hongoh, Y., and Ohkuma, M. (2011). "Termite gut flagellates and their methanogenic and eubacterial symbionts," in Microbiology Monographs: (Endo) Symbiotic Methanogenic Archaea, ed J. H. P. Hackstein (Berlin: SpringerVerlag), 55-79.
Hou, E., Tang, S., Chen, C., Kuang, Y., Lu, X., Heenan, M., et al. (2018) Solubility of phosphorus in subtropical forest soils as influenced by lowmolecular organic acids and key soil properties. Geoderma 313, 172-180. doi: 10.1016/j.geoderma.2017.10.039

Hu, J., Xue, D., Ma, C., and Wang, S. (2004). Research advances in plant growthpromoting rhizobacteria and its application prospects. Chin. J. Appl. Ecol. 15, 1963-1966.

Insam, H., and Goberna, M. (2004). Use of biolog for the community level physiological profiling (CLPP) of environmental samples. Mol. Microb. Ecol. Manual 4, 853-860. doi: 10.1007/978-1-4020-2177-0_4

Jiang, Z., Li, P., Wang, Y., Li, B., and Wang, Y. (2013). Effects of roxarsone on the functional diversity of soil microbial community. Int. Biodeter. Biodegrad. 76, 32-35. doi: 10.1016/j.ibiod.2012.06.010

Klindworth, A., Pruesse, E., Schweer, T., Peplies, J., Quast, C., Horn, M., et al. (2013). Evaluation of general 16S ribosomal RNA gene PCR primers for classical and next-generation sequencing-based diversity studies. Nucleic Acids Res. 41:e1. doi: 10.1093/nar/gks808

Knops, J. M. H., Bradley, K. L., and Wedin, D. A. (2002). Mechanisms of plant species impacts on ecosystem nitrogen cycling. Ecol. Lett. 5, 454-466. doi: 10.1046/j.1461-0248.2002.00332.x

Koch, H., Lücker, S., Albertsen, M., Kitzinger, K., Herbold, C., Spieck, E., et al. (2015). Expanded metabolic versatility of ubiquitous nitrite-oxidizing bacteria from the genus nitrospira. Proc. Natl. Acad. Sci. U.S.A. 112, 11371-11376. doi: 10.1073/pnas.1506533112.

Kodama, Y., Shumway, M., and Leinonen, R. (2011). The Sequence Read Archive: explosive growth of sequencing data. Nucleic Acids Res. 40, D54-D56. doi: $10.1093 /$ nar/gkr854

Kolton, M., Graber, E. R., Tsehansky, L., Elad, Y., and Cytryn, E. (2017). Biochar-stimulated plant performance is strongly linked to microbial diversity and metabolic potential in the rhizosphere. N. Phytol. 213, 1393-1404. doi: $10.1111 /$ nph.14253

Kotroczó, Z., Veres, Z., Fekete, I., Krakomperger, Z., Tóth, J. A., Lajtha, K., et al. (2014). Soil enzyme activity in response to longterm organic matter manipulation. Soil Biol. Biochem. 70, 237-243. doi: 10.1016/j.soilbio.2013.12.028

Li, H., Xiao, J., Gao, Y. Q., Tang, J. J., Zhang, A. L., and Gao, J. M. (2014). Chaetoglobosins from Chaetomium globosum, an endophytic fungus in Ginkgo biloba, and their phytotoxic and cytotoxic activities. J. Agric. Food Chem. 62, 3734-3741. doi: 10.1021/jf500390h

Li, Y., Hu, X., Yang, S., Zhou, J., Zhang, T., Qi, L., et al. (2017). Comparative analysis of the gut microbiota composition between captive and wild forest musk deer. Front. Microbiol. 8:1705. doi: 10.3389/fmicb.2017.01705

Li, Z. G., Luo, Y. M., and Teng, Y. (2008). Soil and Environmental Microbial Methodology. Beijing: Science Press.

Liu, E., Yan, C., Mei, X., He, W., Bing, S. H., Ding, L., et al. (2010). Longterm effect of chemical fertilizer, straw, and manure on soil chemical and biological properties in northwest china. Geoderma 158, 173-180. doi: 10.1016/j.geoderma.2010.04.029

Liu, G. T., Qian, Y. Z., Zhang, P., Dong, Z. M., Shi, Z. Y., Zhen, Y. Z., et al. (1991). Relationships between Alternaria alternata and oesophageal cancer. IARC Sci. Publ. 105, 258-262.

Logrieco, A., Moretti, A., and Solfrizzo, M. (2009). Alternaria toxins and plant diseases: an overview of origin, occurrence and risks. World Mycotoxin J. 2, 129-140. doi: 10.3920/WMJ2009.1145

Long, S. R. (2001). Genes and signals in the Rhizobium-legume symbiosis. Plant Physiol. 125, 69-72. doi: 10.1104/pp.125.1.69

Lu, R. (2000). Method of Soil Agrochemical Analysis. Beijing: Chinese Agricultural Science and Technology Press (in Chinese).

Lücker, S., Wagner, M., Maixner, F., Pelletier, E., Koch, H., Vacherie, B., et al. (2010). A Nitrospira metagenome illuminates the physiology and evolution of globally important nitrite-oxidizing bacteria. Proc. Natl. Acad. Sci. U.S.A. 107, 13479-13484. doi: 10.1073/pnas.1003860107

Lugtenberg, B. (2015). "Introduction to plant-microbe interactions," in Principles of Plant-Microbe Interactions, ed B. Lugtenberg (New York, NY; Cham: Springer), 1-2. doi: 10.1007/978-3-319-08575-3_1

Marschner, P. (2012). "Rhizosphere biology," in Marschner's Mineral Nutrition of Higher Plants, 3rd Edn, ed P. Marschner (New York, 
NY: Academic Press), 369-388. doi: 10.1016/B978-0-12-384905-2. 00015-7

Mazzola, M., Hewavitharana, S. S., and Strauss, S. L. (2015). Brassica seed meal soil amendments transform the rhizosphere microbiome and improve apple production through resistance to pathogen reinfestation. Phytopathology 105, 460-469. doi: 10.1094/PHYTO-09-140247-R

Mendes, R., Garbeva, P., and Raaijmakers, J. M. (2013). The rhizosphere microbiome: significance of plant beneficial, plant pathogenic, and human pathogenic microorganisms. FEMS Microbiol. Rev. 37, 634-663. doi: 10.1111/1574-6976.12028

Miao, Y., Stewart, B. A., and Zhang, F. (2011). Long-term experiments for sustainable nutrient management in China. A review. Agron. Sustain. Dev. 31, 397-414. doi: 10.1051/agro/2010034

Mohammadi, K. (2012). Phosphorus solubilizing bacteria: occurrence, mechanisms and their role in crop production. Resour. Environ. 2, 80-85. doi: $10.5923 /$ j.re.20120201.10

Mommer, L., Hinsinger, P., Prigent-Combaret, C., and Visser, E. J. (2016). Advances in the rhizosphere: stretching the interface of life. Plant Soil. 407, 1-8. doi: 10.1007/s11104-016-3040-9

Montemurro, N., and Visconti, A. (1992). "Alternaria metabolites-chemical and biological data"in Alternaria Biology Plant Diseases and Metabolites, eds J. Chelkowski and A. Visconti (Amsterdam: Elsevier), 449-557.

Montes-Borrego, M., Navas-Cortés, J. A., and Landa, B. B. (2013). Linking microbial functional diversity of olive rhizosphere soil to management systems in commercial orchards in southern Spain. Agric. Ecosyst. Environ. 181, 169-178. doi: 10.1016/j.agee.2013.09.021

Mueller, O., Hahnenberger, K., Dittmann, M., Yee, H., Dubrow, R., Nagle, R., et al. (2000). A microfluidic system for high-speed reproducible DNA sizing and quantitation. Electrophoresis Int. J. 21, 128-134. doi: 10.1002/(SICI)15222683(20000101)21:1<128::AID-ELPS128>3.0.CO;2-M

Myers, M. G., and McGarity, J. W. (1968). The urease activity in profiles of five great soil groups from northern New South Wales. Plant Soil 28, 25-37. doi: 10.1007/BF01349175

Nelson, D. W., and Sommers, L. E. (1996). "Total carbon, organic carbon, and organic matter," in Methods of Soil Analysis. Part 3. Chemical Methods. Soil Science Society of America, Book Series 5, eds D. L. Sparks, A. L. Page, P. A. Helmke, R. H. Loeppert, P. N. Soltanpour, M. A. Tabatabai, C. T. Johnson, and M. E. Sumner (Madison City, WI: SSSA), 961-1010.

Neumann, G., and Römheld, V. (2014). "Rhizosphere chemistry in relation to plant nutrition," in Marschner's Mineral Nutrition of Higher Plants, 3rd Edn. ed P. Marschner (London: Elsevier), 347-368.

Oberhänsli, T., Défago, G., and Haas, D. (1991). Indole-3-acetic acid (IAA) synthesis in the biocontrol strain CHA0 of Pseudomonas fluorescens: role of tryptophan side chain oxidase. Microbiology 137, 2273-2279. doi: 10.1099/00221287-137-10-2273

Oerke, E. C., Dehne, H. W., Schonbeck, F., and Weber, A. (1994). Crop Protection and Crop Production. Amsterdam: Elsevier.

Paz-Ferreiro, J., and Fu, S. (2016). Biological indices for soil quality evaluation: perspectives and limitations. Land Degrad. Dev. 27, 14-25. doi: 10.1002/ldr.2262

Perfect, S. E., Hughes, H. B., O'Connell, R. J., and Green, J. R. (1999). Colletotrichum: a model genus for studies on pathology and fungal-plant interactions. Fungal Genet. Biol. 27, 186-198. doi: 10.1006/fgbi.1999.1143

Peterson, E. A., Gillespie, D. C., and Cook, F. D. (1966). A wide-spectrum antibiotic produced by a species of Sorangium. Can. J. Microbiol. 12, 221-230. doi: $10.1139 / \mathrm{m} 66-031$

Philippot, L., Raaijmakers, J. M., Lemanceau, P., and Van Der Putten, W. H. (2013). Going back to the roots: the microbial ecology of the rhizosphere. Nat. Rev. Microbiol. 11:789. doi: 10.1038/nrmicro3109

Preston-Mafham, J., Boddy, L., and Randerson, P. F. (2002). Analysis of microbial community functional diversity using sole-carbonsource utilisation profiles-a critique. FEMS Microbiol. Ecol. 42, 1-14. doi: 10.1111/j.1574-6941.2002.tb00990.x

Puglisi, E., Del Re, A. A. M., Rao, M. A., and Gianfreda, L. (2006). Development and validation of numerical indexes integrating enzyme activities of soils. Soil Biol. Biochem. 38, 1673-1681. doi: 10.1016/j.soilbio.2005.11.021
Qiao, H., Zhang, L., Shi, H., Song, Y., and Bian, C. (2018). Astragalus affects fecal microbial composition of young hens as determined by $16 \mathrm{~S}$ rRNA sequencing. AMB Express 8:70. doi: 10.1186/s13568-018-0600-9

Qiu, M., Li, S., Zhou, X., Cui, X., Vivanco, J. M., Zhang, N., et al. (2014). Decoupling of root-microbiome associations followed by antagonist inoculation improves rhizosphere soil suppressiveness. Biol. Fertil. Soils 50, 217-224. doi: 10.1007/s00374-013-0835-1

Raaijmakers, J. M., Paulitz, T. C., Steinberg, C., Alabouvette, C., and MoënneLoccoz, Y. (2009). The rhizosphere: a playground and battlefield for soilborne pathogens and beneficial microorganisms. Plant Soil 321, 341-361. doi: 10.1007/s11104-008-9568-6

Reichenbach, H. (2006). "The genus Lysobacter," in The Prokaryotes, eds M. Dworkin M, S. Falkow, E. Rosenberg, K. H. Schleifer, E. Stackebrandt (New York, NY: Springer), 939-957. doi: 10.1007/0-387-30746-X_37

Robertson, G. P., and Groffman, P. M. (2007). "Nitrogen transformations," in Soil Microbiology, Ecology and Biochemistry, 3rd Edn., eds G. P. Robertson, P. M. Groffman (San Diego: Academic Press), 341-364.

Roscoe, R., Vasconcellos, C. A., Furtini-Neto, A. E., Guedes, G. A., and Fernandes, L. A. (2000). Urease activity and its relation to soil organic matter, microbial biomass nitrogen and urea-nitrogen assimilation by maize in a Brazilian Oxisol under no-tillage and tillage systems. Biol. Fert. Soils 32, 52-59. doi: $10.1007 / \mathrm{s} 003740000$

Rousk, J., Bååth, E., Brookes, P. C., Lauber, C. L., Lozupone, C., Caporaso, J. G., et al. (2010). Soil bacterial and fungal communities across a ph gradient in an arable soil. ISME J. 4, 1340-1351. doi: 10.1038/ismej. 2010.58

Rutgers, M., Wouterse, M., Drost, S. M., Breure, A. M., Mulder, C., Stone, D., et al. (2016). Monitoring soil bacteria with community-level physiological profiles using Biolog TM ECO-plates in the Netherlands and Europe. Appl. Soil Ecol. 97, 23-35. doi: 10.1016/j.apsoil.2015. 06.007

Sardans, J., Peñuelas, J., and Estiarte, M. (2008). Changes in soil enzymes related to $\mathrm{C}$ and $\mathrm{N}$ cycle and in soil $\mathrm{C}$ and $\mathrm{N}$ content under prolonged warming and drought in a Mediterranean shrubland. Appl. Soil Ecol. 39, 223-235. doi: 10.1016/j.apsoil.2007.12.011

Schinner, F., and Von Mersi, W. (1990). Xylanase-, CM-cellulase-and invertase activity in soil: an improved method. Soil Biol. Biochem. 22, 511-515. doi: 10.1016/0038-0717(90)90187-5

Schutter, M., and Dick, R. (2001). Shifts in substrate utilization potential and structure of soil microbial communities in response to carbon substrates. Soil Biol. Biochem. 33, 1481-1491. doi: 10.1016/S0038-0717(01)00057-8

Sharma, S., Rangger, A., and Insam, H. (1998). Effects of decomposing maize litter on community level physiological profiles of soil bacteria. Microb. Ecol. 35, 301-310. doi: 10.1007/s002489900085

Singh, R. P., Kothari, R., Koringa, P. G., and Singh, S. P. (2017). "Plant-Pathogen Interactions: a proteomic approach," in Understanding Host-Microbiome Interactions-An Omics Approach, eds A. Kaur, A. Kumar, and M. Sudhakara Reddy (Singapore: Springer), 207-226.

Soni, R., Kapoor, R., and Kaur, M. (2016). Evaluation of siderophore production and antimicrobial activity by fluorescent 'Pseudomonas' diversity associated with rhizosphere of apple and pear. Int. J. Agric. Environ. Biotechnol. 9:1109. doi: 10.5958/2230-732X.2016.00140.6

Srivastava, A. K., Malhotra, S. K., and Krishna Kumar, N. K. (2015). Exploiting nutrient-microbe synergy in unlocking productivity potential of perennial fruits: a review. Indian J. Agric. Sci. 85, 459-481.

Sugiyama, A., Ueda, Y., Zushi, T., Takase, H., and Yazaki, K. (2014). Changes in the bacterial community of soybean rhizospheres during growth in the field. PLoS ONE 9:e100709. doi: 10.1371/journal.pone.0100709

Sukumar, P.,Legué, V., Vayssières, A., Martin, F., Tuskan, G. A., and Kalluri, U. C. (2013). Involvement of auxin pathways in modulating root architecture during beneficial plant-microorganism interactions. Plant Cell Environ. 36, 909-919. doi: $10.1111 /$ pce. 12036

Tian, Y., and Zhang, Z. (2017). "Main management techniques of deciduous fruit trees in northern China," in Practical Techniques and Information about Fruit Trees, 4-5.

Toju, H., Tanabe, A. S., Yamamoto, S., and Sato, H. (2012). Highcoverage ITS primers for the DNA-based identification of ascomycetes 
and basidiomycetes in environmental samples. PLoS ONE 7:e40863. doi: 10.1371/journal.pone.0040863

Torsvik, V., Øvreås, L., and Thingstad, T. F. (2002). Prokaryotic diversitymagnitude, dynamics, and controlling factors. Science 296, 1064-1066. doi: $10.1126 /$ science. 1071698

Urbanová, M., Šnajdr, J., and Baldrian, P. (2015). Composition of fungal and bacterial communities in forest litter and soil is largely determined by dominant trees. Soil Biol. Biochem. 84, 53-64. doi: 10.1016/j.soilbio.2015. 02.011

Watanabe, M., Yonezawa, T., Lee, K., Kumagai, S., Sugita-Konishi, Y., Goto, K., et al. (2011). Molecular phylogeny of the higher and lower taxonomy of the Fusarium genus and differences in the evolutionary histories of multiple genes. BMC Evol. Biol. 11:322. doi: 10.1186/1471-2148-11-322

Weand, M. P., Arthur, M. A., Lovett, G. M., McCulley, R. L., and Weathers, K. C. (2010). Effects of tree species and $\mathrm{N}$ additions on forest floor microbial communities and extracellular enzyme activities. Soil Biol. Biochem. 42, 2161-2173. doi: 10.1016/j.soilbio.2010.08.012

Weigele, M., and Leimgruber, W. (1967). The structure of myxin. Tetrahedron Lett. 8, 715-718. doi: 10.1016/S0040-4039(00)90579-3

Wood, R. K. S., Ballio, A., and Graniti, A. (1972). Phytotoxins in plant diseases. Phytotoxins Plant Dis. 99, 318. doi: 10.2307/2997079

Wu, L., Li, Z., Li, J., Khan, M. A., Huang, W., Zhang, Z., et al. (2013). Assessment of shifts in microbial community structure and catabolic diversity in response to Rehmannia glutinosa monoculture. Appl. Soil Ecol. 67, 1-9. doi: 10.1016/j.apsoil.2013.02.008

Yang, J., Kloepper, J. W., and Ryu, C. M. (2009). Rhizosphere bacteria help plants tolerate abiotic stress. Trends Plant Sci. 14, 1-4. doi: $10.1016 /$ j.tplants.2008.10.004
Yao, K. Y., and Huang, C. Y. (2006). Soil Microbial Ecology and Experimental Techniques. Beijing: Science Press.

Yu, H., Si, P., Shao, W., Qiao, X., Yang, X., Gao, D., et al. (2016). Response of enzyme activities and microbial communities to soil amendment with sugar alcohols. MicrobiologyOpen 5, 604-615. doi: 10.1002/mbo3.355

Zhang, C., Liu, G., Xue, S., and Song, Z. (2011). Rhizosphere soil microbial activity under different vegetation types on the Loess Plateau, China. Geoderma 161, 115-125. doi: 10.1016/j.geoderma.2010.12.003

Zhang, F. S., Shen, J. B., and Feng, G. (2009). Rhizosphere Ecology. Beijing: China Agricultural University Press.

Zhang, H., Shao, M., Huang, H., Wang, S., Ma, L., Wang, H., et al. (2018). The dynamic distribution of small-tail han sheep microbiota across different intestinal segments. Front. Microbiol. 9:32. doi: 10.3389/fmicb.2018.00032

Zhang, Q., Li, H. Q., Zong, S. C., Gao, J. M., and Zhang, A. L. (2012). Chemical and bioactive diversities of the genus Chaetomium secondary metabolites. Mini Rev. Med. Chem. 12, 127-148. doi: 10.2174/138955712798995066

Conflict of Interest Statement: The authors declare that the research was conducted in the absence of any commercial or financial relationships that could be construed as a potential conflict of interest.

Copyright (c) 2018 Si, Shao, Yu, Yang, Gao, Qiao, Wang and Wu. This is an openaccess article distributed under the terms of the Creative Commons Attribution License (CC BY). The use, distribution or reproduction in other forums is permitted, provided the original author(s) and the copyright owner(s) are credited and that the original publication in this journal is cited, in accordance with accepted academic practice. No use, distribution or reproduction is permitted which does not comply with these terms. 